On the road to carbon reduction in a food supply network: A complex adaptive systems perspective

\begin{tabular}{|r|l|}
\hline Journal: & Supply Chain Management: an International Journal \\
\hline Manuscript ID & SCM-06-2017-0214.R3 \\
\hline Manuscript Type: & Original Manuscript \\
\hline Keywords: & $\begin{array}{l}\text { Supply-chain management, Sustainability, Complexity, Climate change, } \\
\text { Carbon Management }\end{array}$ \\
\hline \multicolumn{2}{|l}{} \\
\hline
\end{tabular}

SCHOLARONE $^{\text {M }}$
Manuscripts 


\title{
On the road to carbon reduction in a food supply network: A complex adaptive systems perspective
}

\begin{abstract}
Purpose: In acknowledging the reality of climate change, large firms have set internal and external (supplier oriented) targets to reduce their greenhouse gas (GHG) emissions. This study explores the complex processes behind the evolution and diffusion of carbon reduction strategies in supply networks.
\end{abstract}

Design/methodology/approach: The research uses complex adaptive systems (CAS) as a theoretical framework and presents a single case study of a focal buying firm and its supply network in the food sector. A longitudinal and multilevel analysis is used to discuss the dynamics between the focal firm, the supply network and external environment.

Findings: Rather than being a linear and controlled process of adoption-implementationoutcomes, the transition to reduce carbon in a supply network is much more dynamic, emerging as a result of a number of factors at the individual, organizational, supply network and environmental levels.

Research limitations/implications: The research considers the emergence of a carbon reduction strategy in the food sector, driven by a dominant buying firm. Future research should seek to investigate the diffusion of environmental strategies more broadly and in other contexts.

Practical implications: Findings from the research reveal the limits of the control that a buying firm can exert over behaviours in its network and show the positive influence of consortia initiatives on transitioning to sustainability in supply networks.

Originality: CAS is a fairly novel theoretical lens for researching environmental supply network dynamics. The paper offers fresh multilevel insights into the emergent and systemic nature of the diffusion of environmental practices in supply networks.

Keywords: Sustainable supply networks; climate change; carbon reduction; complex adaptive systems; consortium; case study

Paper type: Case study

\section{Introduction}

In the last four decades, sustainability has become a useful umbrella concept for thinking about the relationship between the economic and environmental systems but its high level of 
abstraction and complexity makes it difficult to operationalise at the level of the supply network (Carter and Rogers, 2008, Matthews et al., 2016). A recent management paper has encouraged scholars to start conducting research into the relationship between supply networks and specific environmental problems in order to produce more fine-grained accounts of corporate sustainability strategies (Whiteman et al., 2013).

This paper responds to this call by focusing on the issue of anthropogenic climate change as it one of the most serious man-made environmental problems (IPCC, 2013). Climate change is thought to be contributing towards phenomena such as water scarcity and accelerated rates of species extinction (WWF, 2014). Consequently, there is broad agreement within the discourse on sustainability that the sustainable economy will need to be a lowcarbon economy (IPCC, 2007, OECD, 2010, UNEP, 2011, WRI, 1998), and carbon reduction is often seen as a proxy for sustainability performance (Bai et al., 2012).

Climate change is a system-level challenge that cannot be resolved at the level of the firm. Firms will need to pursue cooperative inter-organizational strategies in order to effectively mitigate climate change (Pinkse and Kolk, 2010). In a scenario where competition takes place between supply networks (Lamming et al., 2000, Bakker and Kamann, 2007), instead of between isolated firms, a buying firm is deemed to be no more sustainable than its suppliers (Caniëls et al., 2013, Krause et al., 2009, Lee et al., 2013). Buying firms are liable for emissions not only within their own boundaries, but also across their extended supply networks (Hartmann and Moeller, 2014). Efforts to transform processes and practices in order to significantly reduce carbon emissions require the efforts of interconnected actors in supply networks, including dominant buying firms and their suppliers (Lee and Klassen, 2008, Nair et al., 2016, Lee, 2008), as well as non-traditional stakeholders such as NGOs (Gold et al., 2013, Rodríguez et al., 2016). These connections are complex and one cannot assume that 
environmental strategies and innovations will diffuse linearly and in a predictable manner (Nair et al., 2016).

Yet most research on sustainable supply chain management (SSCM) and green SCM has been rooted in assumptions of linearity and control, with a primary focus on the relationships between dominant buyers and first-tier suppliers (Miemczyk et al., 2012, Carter and Easton, 2011). Research considering carbon reduction strategies within supply networks is no different. It has particularly focused on issues related to carbon emissions and auditing (Lee and Cheong, 2011, Lee, 2012, Lee, 2011, McKinnon, 2010), to commercial and legal pressures for carbon emissions reduction (Zhu et al., 2013, Hitchcock, 2012, Zhu and Geng, 2013) and to the development of decision-support models (Koh et al., 2013, Hsu et al., 2013a, Hsu et al., 2013b). Little empirical evidence and theoretical discussion of the unfolding of the transition to low-carbon supply networks has been presented to date.

Hence there are opportunities to expand the scope of scholarship in this area from the linearity of direct buyer-supplier relationships to multi-tier and multilateral studies (Walker et al., 2014, Tachizawa and Wong, 2014) and to consider ways in which environmental strategies proliferate and are shaped through the network. In attempting to address the identified shortcomings of current research, we pose the following question, as the overarching aim of our research: How does a carbon reduction strategy emerge in a supply network?

In this research, we embrace the view that carbon reduction in supply networks is nonlinear and emerges through a negotiation process between the actors in these networks. In addressing the overarching question, we aim to shed light on this negotiation process and more specifically explore the influence of the interactions between different agents within the supply network on the implementation of a carbon reduction strategy, the main changes and events that shape the process, and the challenges encountered in the process. 
Our study frames a supply network as a 'complex adaptive system' (CAS), i.e. a dynamic system that is difficult to predict and control (Choi et al., 2001, Carter et al., 2015b). While CAS has been used to analyse supply networks (Pathak et al., 2007, Nair et al., 2009, Choi et al., 2001, Surana et al., 2005), studies specifically using CAS as a framework in the field of SSCM remain scarce. A notable exception is the work of Nair and colleagues on environmental innovation diffusion (Nair et al., 2016) that calls for more research around supply network dynamics associated with positive changes such as environmental strategies. We subscribe to their definition of diffusion as a process by which ideas propagate across supply networks and amplification as the process within which a wide diversity of external organizations, besides the buying firm's suppliers, are involved in innovation or change processes more generally (Nair et al., 2016).

We employ a multilevel analysis to map factors that play out in the evolution of a carbon reduction strategy in a supply network. Through the lens of CAS, we discuss the processes at play in moving towards more sustainable supply networks.

In order to capture the complexity of a supply network, we focus on a carbon reduction strategy implemented in the supply network of a large buying firm in the food sector. The food system is under increasing public scrutiny regarding carbon emissions (Maloni and Brown, 2006, van der Vorst et al., 2009). Food production presents a significant challenge regarding energy consumption because it requires vast amounts of natural resources, such as water, land and energy, making the sector a constant focus of climate change regulation in several countries (Mena et al., 2014). Nevertheless, there is lack of research on large-scale carbon reduction initiatives in food supply networks. Our study provides an in-depth account of the emergence and diffusion of a carbon reduction initiative that has the goal of diffusing a farm-based tool that can track carbon emissions and support the development of carbon reduction strategies across a supply network. 
The remainder of this paper is structured as follows. The next section presents a review of the literature concerning food supply networks and carbon reduction strategies. The CAS framework and research question are presented in the third section. The fourth section presents the research design. The fifth section presents the case study findings, which are then addressed in section six. In the discussion, we formulate a number of propositions and articulate the managerial implications of the research. Finally, the paper concludes with research limitations and recommendations for future research.

\section{Literature review}

\subsection{Food supply network research}

The steady growth of the food sector in the last few decades has broadened food distribution from a local to a global scale (Rodrigue, 2012). Forecasts suggest that growth will continue and that by 2050 , the world will need to feed more than nine billion people, requiring nearly $70 \%$ more food than is consumed today (Denis et al., 2015). Despite the scale of production within the food sector and concentration of firms within it (Beske et al., 2014), the upstream processes of fresh food produce, such as agriculture and dairy production, remain characterised by a dispersed base of smallholder farms, i.e. family-run businesses where control stays within the family through generations (Ehrgott et al., 2011).

The complex and dispersed food industry faces many pertinent corporate social responsibility issues (Pullman et al., 2009); is highly exposed to public criticism (Maloni and Brown, 2006, van der Vorst et al., 2009); and faces significant risks especially with regards to agricultural sustainability (Hamprecht et al., 2005). This has been demonstrated through a number of high-profile scandals, including the horsemeat scandal in Europe and the case of Norwegian salmon production. As a result, there is a growing concern about the social and 
environmental issues related to food production (Vasileiou and Morris, 2006) and the role of leading multinationals within food systems (Whipple et al., 2009).

The food system is embedded within distinctive social, economic and environmental processes (Thompson and Scoones, 2009) and the increasing drive to manage these and demonstrate good performance in this area has driven the proliferation of sustainability standards (Tallontire, 2007, Henson and Humphrey, 2008). Several companies have begun addressing these sustainability issues by developing or adopting existing standards and certifications, participating in sustainability programs, and defining new modes of governance for food production process (Henson and Humphrey, 2008). Yet the sharing of sustainability performance gains and the bearing of the investment required is likely to be impacted by the power imbalances characterising food supply networks (Pullman et al., 2009, Cox et al., 2007).

Traditionally, buyer-supplier relationships in food supply networks are predominantly adversarial and focused on direct suppliers (Mena et al., 2013) and often firms have addressed sustainability through a risk-perspective setting controls to track the risk of supplier misconduct (Seuring and Müller, 2008). However, as sustainability pressures intensify, buying firms are slowly moving toward a collaborative approach to suppliers and sub-suppliers (Grimm et al., 2014). Supplier development programmes may include transfer of knowledge, resources and the deployment of new organizational practices (Bai and Sarkis, 2010). Recent literature has mapped the cases of Waitrose (Spence and Bourlakis, 2009), Nestlé (Alvarez et al., 2010), and Danone (Gold et al., 2013) as evidence of a shift toward more collaborative approaches to smallholder farms.

\subsection{Carbon reduction in food supply networks: between control and emergence}

For many food firms, the carbon impact of their suppliers is several orders of magnitude greater than that of their own operations (WRI and WBCSD, 2009), however only $10 \%$ of 
companies actively measure their supply network's carbon emissions (Accenture, 2009). Achieving carbon reductions requires calculation of the impact of both direct and indirect emissions (Lee, 2012); engagement and commitment throughout the supply network (Koh et al., 2013); and a monitoring process to ensure improvements are occurring.

Carbon emissions, one component of life-cycle analysis (LCA), has increasingly been applied by large companies not just at individual ingredient or product level but beyond this to assess brand product portfolios (Milà i Canals et al., 2010) and even across their entire supply networks (Lee, 2011). This has been driven at least in part, by increased recognition of the need to take responsibility for and include scope 3 greenhouse gas (GHG) emissions, those outside the direct influence of the company, if they are to truly reduce the impacts associated with their business practices (CarbonTrust, 2006). Pressures from governments and consumers who are relying on large multi-national companies (MNCs) to reduce their full value chain GHG emissions through regulatory (e.g. Carbon Reduction Commitment (CRC)) and voluntary initiatives (e.g. certification of products; environmental product declarations (EPDs)), have further exacerbated the need to address supply network emissions.

Previously however, agricultural emissions were omitted from greenhouse gas (GHG) inventories (Russell, 2011) for a number of reasons including lack of scientific consensus for accounting methodologies; large uncertainties in terms of the impact of carbon mitigation strategies; and difficulties in gathering data over different spatial and temporal dimensions. Over the last decade, a number of LCA-based carbon reporting tools have been developed in the agricultural sector, particularly in the United Kingdom (UK) (Whittaker et al., 2013). These tools vary in how they account for GHG emissions from the various activities involved in agriculture. There is consensus however around the fact that such tools do provide a way to "educate" farmers about sources of emissions and climate change generally, and can serve to 
facilitate more transparent information sharing between the parties involved in agricultural products chains (Whittaker et al., 2013).

The literature has produced an impressive body of knowledge on how focal firms work towards driving down carbon emissions within their supply networks. These insights include the drivers, pressures and motives for transitioning to low-carbon supply networks (Hitchcock, 2012, Hua et al., 2011); the approaches and methodologies for carbon reduction (CarbonTrust, 2006); and supply network design and operational decision making (Benjaafar et al., 2013, Chaabane et al., 2012, Cholette and Venkat, 2009, Jones, 2002), showing that collaboration and communication both play key roles in effectuating carbon reduction strategies. Open communication helps strengthening relationships across the supply network (Mena et al., 2013). Through collaborative activities based on open communication, firms learn how to assimilate information and transfer experiences across organizational boundaries, thus characterising communication and collaboration as essential components to drive reduction in carbon emissions across the supply network (Theißen et al., 2014).

Much of the SSCM literature stresses the potential for focal firms to control their supply networks and shift them towards a more sustainable trajectory, as can be seen in the following definition: 'SSCM is the designing, organizing, coordinating and controlling of supply chains to become truly sustainable”' (Pagell and Shevchenko, 2014).

This emphasis on control makes sense as SSCM studies are often concerned with the deliberate strategies of the buying firms within a supply network. However, this focus has created a gap in the literature as we rarely consider the emergent aspects of SSCM strategies, i.e. the interactions between buying firms and suppliers, which may be significantly different from intended behaviour, e.g. through the resistance of some supply network agents (Touboulic et al., 2014). This may be due to a tendency to over-emphasize the deliberate aspects of SSCM strategies at the expense of their more emergent aspects. To explore the 
non-deliberate aspects of a carbon focussed SSCM strategy, we adopt Mintzberg and Waters' (1985) concept of strategy in which strategy consists of both deliberate and emergent strategies.

Deliberate strategy is strategy that was intended and realized, whereas emergent strategy consists of the responses to unanticipated events that were not intended and were not originally formulated as part of the strategy to be implemented (Mintzberg and Waters, 1985). Using this construction of strategy to look at carbon reduction strategies within a supply network leads us to question the linear view of the carbon reduction process in which the focal firm in a supply network formulates the carbon reduction strategy and the suppliers simply implement it unquestioningly and unproblematically. Instead, it opens up the possibility that the carbon reduction strategy that is implemented will be different from the formulated strategy as the focal firm and its suppliers negotiate its meaning, manage tensions between their interests and respond to unanticipated events.

By ignoring the emergent aspects of SSCM strategies, the literature has tended to bracket the question of how suppliers engage with, or indeed fail to engage with, the carbon reduction strategies of their buyers. This leads to supplier engagement being assumed rather than being a phenomenon to be investigated empirically. Given that supplier engagement is considered a prerequisite for a successful carbon reduction strategy within a supply network (OECD, 2010), this represents a significant gap within the literature.

\section{Conceptual framework: sustainable supply networks as complex adaptive systems}

In order to study the emergence of carbon reduction strategies, our study frames a supply network as a CAS, that is "dynamic, complex, and difficult to predict and control" (Carter et al., 2015b). Because of the complexity of supply networks, it is believed that it is a difficult, 
resource intensive process to effect meaningful changes within them (Choi et al., 2001, Carter et al., 2015b), such as transitioning them towards a more environmentally sustainable path. To overcome these challenges there has been a rise in network-level collaborations (Bendell et al., 2010, Hamprecht et al., 2005, Fadeeva, 2005). Figure 1 presents the original CAS framework.

As can be seen from the above figure, the CAS framework has three dimensions: internal mechanisms, environment and co-evolution. CAS posits that the behaviour of a supply network is determined by the interaction of the agents within the system. Agents can be individuals or organizations. The behaviour of agents is determined by their schema, i.e. their “norms, values, beliefs, and assumptions"' (Choi et al., 2001), and will determine how agents make sense of environmental pressures external to the supply network and the behaviour of other agents within the network, e.g. buyers trying to understand the behaviour of their suppliers. In order to make supply networks more sustainable, agents will need to share a schema that attaches the highest importance to sustainability. If sustainability is attached a secondary importance within the schema of agents, the transition to sustainability will be more difficult. In such instances, focal firms may attempt to change the schema of their suppliers, e.g. through supplier development.

A CAS is self-organizing (Pathak et al., 2007) and the structure of a CAS is determined by the interaction among agents. It cannot be assumed that one agent within a supply network is able to determine its structure and control its evolution. The emergent structures of a supply network will necessarily evolve in ways that have not been anticipated. Hence, unilateral 
movements from the focal firm may be ineffective if they build resistance from other agents in a CAS.

The complexity of a CAS is determined by its levels of connectivity and dimensionality (Choi et al., 2001). Connectivity can be measured both quantitatively and qualitatively as the number of connections that exist between agents within the network and the way in which they are connected. Quantity and quality are not necessarily related as agents who are weakly tied may have high quality connections, i.e. because they are unknown to each other the agents may be able to exchange novel knowledge (Granovetter, 1973). The level of connectivity within the CAS will also influence its dimensionality, i.e. the degree to which agents can behave autonomously. At low levels of connectivity, agents have high levels of autonomy and the CAS will emerge in ways that are difficult, if not impossible, to predict or control. Higher levels of connectivity may decrease the autonomy of agents, but this is not always desirable, e.g. in the area of innovation, some degree of autonomy is necessary (Nair et al., 2016).

The external environment of a CAS is a major influence on its self-organization and emergence. Analysis using the CAS lens needs to be sensitive to what is happening in the environment of the CAS and how agents are responding to these environmental changes. To understand the environment, the CAS framework provides two concepts: rugged landscapes and dynamism (Choi et al., 2001). Rugged landscapes are environments that are difficult to map and make sense of. This makes it difficult for the CAS to optimize its performance. Making sense of the environment is further complicated by dynamism. The CAS framework considers that a CAS and its environment will exist together in a process of co-evolution as the CAS both responds to and causes changes within its environment. This means that a CAS will exist in a state of quasi-equilibrium in which there is a constant tension between stability and change. When change does occur it is likely to follow a non-linear pattern (Pathak et al., 
2007), which makes it more difficult to establish causality between action and results. This does not mean however that the evolution of a CAS purely chaotic. Instead, CAS works with the concept of a non-random future in which agents internal and external to a CAS are able to identify patterns within the process of co-evolution.

The above process is characterised by a continuous tension between control and emergence. One agent, for example the focal firm within the supply network, may attempt to exert control over the system but this will depend on their ability to change the schema of other agents and consequently the rules upon which the system is based (Choi et al., 2001). SSCM is the attempt to do precisely this in relation to sustainability but the degree of adaptation possible will likely be constrained by the complexity of the supply network. Moreover, changes in a CAS tend to be non-linear (Pathak et al., 2007), which makes it more difficult to establish causality between action and results. Additionally, changes in a CAS may lead to changes in the wider environment, which in turn may affect the CAS quasiequilibrium (Nair et al., 2009). In brief, the CAS lens explains the complexity of supply networks through a combination of internal mechanisms, the environment and co-evolution (Pathak et al., 2007).

Sustainability represents a good example of this co-evolutionary process. As concerns about the sustainability of the economic system have become widespread in society, the schemas of agents within many supply networks have changed to become more environmentally and socially responsible. Similarly, exemplars in the area of SSCM have influenced the behaviour of other supply networks. Further, connectivity and dimensionality within supply networks has changed as new agents have been brought in to help manage buyer-supplier relationships, such as NGOs, and the autonomy of suppliers in relation to social and environmental concerns has been reduced as the focal firms within supply networks have increased their monitoring of suppliers in these areas. As supply networks 


\section{Research Design}

Our research approach is qualitative. There is a limited amount of research that has explored the emergent aspects of SSCM strategies. We were not interested in providing large quantitative data related to carbon reduction but rather in gaining in-depth insights into the transformation process required to reduce carbon emissions within a supply network, which provides us with the opportunity to engage in theory elaboration. An embedded case study was therefore selected as a suitable methodology because it enabled detailed investigations of organizations and organizational processes to be conducted whilst capturing the contextual factors and social embeddedness of the phenomenon under study (Yin, 2003, Miles and Huberman, 1994). 


\subsection{Case selection}

In case-study research there is a trade-off between using multiple cases to increase the breadth of data and delving deeper in a single case to provide greater depth of analysis. In this study, the researchers have favoured the latter option. This study therefore focuses on a single critical case, and this choice is justified by criticality, uniqueness and opportunity to learn (Stake, 1995), as well as by the labour-intensive nature of a multilevel research (Mena et al., 2013). First, the chosen case study is critical as it represents an exemplar in the industry of a continuous supply-network level effort toward reduction in carbon emissions. Findings from a leading initiative can be useful for benchmarking purposes (Barratt et al., 2011). Second, it is unique because of its engagement in an industry-level consortium in the food sector oriented towards climate change. Finally, a critical case offers the researcher a unique opportunity to analyse a phenomenon previously inaccessible to scientific investigation (Bryman, 2012), in this case to stress existing understanding of SSCM practices.

Supply networks are difficult to capture in their totality and require a labour-intensive data collection (Dubois, 2009). SCM research has increasingly chosen the single-case approach to explore network-level or multi-level analysis, because this strategy facilitates a fuller understanding of the dynamics and different dimensions of the observed phenomenon (Dubois, 2009). Recent examples include the study of a multi-stakeholder programme led by multinational firm aiming to improve sustainability across the supply network (Alvarez et al., 2010) and a multi-tier response to an extreme event, i.e. a disaster (Johnson et al., 2013). In both cases, the boundaries of a network-level case offer fruitful room for contributing to SCM theory.

When case analysis is set at the network-level (or multilevel), there is cross-analysis of multiple sources (Lewis and Brown, 2012). Moreover, single-case research allows a longitudinal account of the dynamics of collaborative efforts (Alvarez et al., 2010), 
supporting theory elaboration. In theory-elaboration studies based on a single case, the sense of generality results from the development of new constructs or new relationships currently not incorporated in the general theory under study, which reconcile theory and the empirical context (Ketokivi and Choi, 2014).

\subsection{Research context}

Multinationals within the food sector are setting themselves ambitious carbon reduction targets in order to make the transition towards low-carbon supply networks. This context allows the analysis of carbon reduction strategies beyond a single firm to explore multilevel collaboration (Carter et al., 2015a) and unveil the competing tensions at each level.

The choice of a single case study has allowed a multilevel analysis (Barratt et al., 2011, Alvarez et al., 2010, Dyer and Wilkins, 1991) that encompasses the consortium level, the firm/supply network level (both the buyer and farmers' perspectives) and the level of individuals (see Figure 2).

\section{INSERT FIGURE 2 HERE}

For the purposes of anonymity, the focal firm will be referred to as FoodDrinkCo (FDC) and the consortium as Sustainable Farming Tool (SFT) throughout the paper. FDC is a multinational firm employing over 250,000 globally and over 5,000 within the UK. The company has been recognised and rewarded for its proactive sustainability engagement over the last 6 years. It is ranked in the Dow Jones Sustainability Index, participates in the United Nations Global Compact and is an active member of the Sustainable Agriculture Initiative Platform. The company has set carbon reduction as a top priority. FDC has extended its sustainability strategy to include its agricultural suppliers in Western and Eastern Europe with 
a focus on radically reducing its upstream carbon emissions. This research focuses on FDC's UK supply network for one agricultural product, referred to as crop A hereafter.

\subsection{Data collection}

We employ a combination of different methods (Eisenhardt and Graebner, 2007, Shah and Corley, 2006), including collection of documents from the case company, participant observations and semi-structured interviews with key stakeholders. One of the researchers was involved in researching the focal company and its supply network over more than five years and regularly attended meetings and other events. Such longitudinal approach allows gathering rich insights. As Van de Ven and Johnson (2006) accurately note, traditional research designs tend to only capture the information that people are willing to share through formal and shallow interviews. They argue that research over an extended period of time will provide greater penetration into the subject matter as a result of the mutual trust developed.

The primary sources of evidence are notes taken during observations and meetings, interviews (43) and workshops (3) conducted with key informants. Details regarding key informants and various primary and secondary data sources are provided in Tables 1, 2 and 3 below.

INSERT TABLE 1 HERE INSERT TABLE 2 HERE INSERT TABLE 3 HERE

Interviews lasted between 30 minutes and 2 hours and followed a semi-structured format, exploring aspects of the relationships between the different parties (buyer, supplier, and consultants, external parties) and experiences with FDC's environmental agenda and approach to carbon reduction. The workshops were organized in Year 3 and Year 4 and 
gathered participants that had taken part in the interviews to provide a space to reflect on interview findings and explore identified issues in more depth, especially around understandings of sustainability and supply network relationships. Interviews and workshops participants were selected based on their level of experience regarding the implementation of the carbon measurement tool. They included purchasing, agriculture, and sustainability managers, supplier informants that had implemented the tool as well as external informants from supporting organizations that were involved alongside FDC (Tables $1 \& 2$ ).

We followed two criteria to guide the number of interviews presented in this study. On the one hand, we aimed to gather a wide breadth of perspectives and include relevant stakeholders in both the focal organizations and across the supply network. On the other hand, theoretical saturation helped us decide when to stop interviewing based on the fact that we were not gaining additional insights (Kaufmann and Denk, 2011). Informants' confidentiality has been protected thereby ensuring credibility and dependability.

\subsection{Data analysis}

Our overall focus for conducting the analysis is FDC's carbon reduction strategy. The data analysis process was based on the principles of abductive reasoning whereby the researchers engaged in a to-and-from between the empirical and the conceptual, in order to make sense of the phenomena under study (Ketokivi and Choi, 2014). In an abductive approach, a theoretical framework is used to inform the data analysis, unlike in inductive approaches, but the analysis is not confined to testing aspects of the theoretical framework as with deductive approaches (Dubois and Gadde, 2002). Instead, the analysis is a process of determining which aspects of the theoretical framework are most salient to the empirical material being analysed (Dubois and Gadde, 2002; Ketokivi and Choi, 2014). In this case, the CAS concept of 'schema' was identified as being one of the most useful for understanding the dynamics of the case. Abductive reasoning is consistent with our theory elaboration approach as it allows 
us to elaborate those aspects of the theoretical framework that are most relevant to the investigation and use the idiosyncrasies of the case being studied to elaborate upon those concepts (Fisher and Aguinis, 2017, Ketokivi and Choi, 2014).

Data coding consisted of three main cycles (Saldaña, 2009). The first cycle was an initial coding (Saldaña, 2009) in order to explore the data and construct initial codes and themes. The researchers paid particular attention to the interactions between agents and how these interactions have influenced the development of the strategy. This has included considering interactions within the supply network but also in terms of involvement in the consortium. This relates to the internal mechanisms, especially connectivity and dimensionality, and the external environment aspects of the CAS framework. More specifically, we have looked at moments when agents' schema clashed or aligned, and how this has moved the network from an inception phase, to an adaptation phase, and finally to quasi-equilibrium. We were interested here in the co-evolution aspect of the CAS framework, and therefore considered the main changes and events as well as the challenges encountered and how they were resolved, and the impact of these on the development of the carbon reduction strategy. Our analysis was multilevel in the sense that it sought to explore the various levels of analysis of the case study as depicted in Figure 2. The different data sources presented in section 4.3 were complementary in building a rich picture of the dynamics at various levels. Interviews were central to understanding the micro individual level as well as the organizational and supply network levels. Workshops and observations provided insights into organizational and supply network levels. Specific meetings at the consortium level provided evidence of the environment level and of the role of boundary spanning individuals. Secondary data was critical in providing contextual information, mapping key events and exploring FDC's schema. Within this initial cycle, we first became aware of existing tensions within and between the levels. 
In the second cycle, we conducted versus coding. In versus coding, concepts, processes and phenomena are contrasted in binary terms; the resulting analysis often adopts the phrases 'on the one hand' and 'on the other hand' to spotlight inherent dilemmas identified in the data analysis (Saldaña, 2009). This coding method was useful to developing understanding of the tensions within each level of analysis. Identified themes were attributed a level. It became apparent that some themes were connecting different levels. For example, we identified "conflict" and "conflict resolution" as key multilevel themes, with evidence at the micro and organizational levels (the individuals and teams within FDC) and the network level (between different agents of the network: FDC and farmers). We focused on teasing out how events at the various levels contributed towards exacerbating or resolving conflict. We also explored the linkages with other themes at the various levels. For instance, we describe later in the paper that a supply network level event - the harvest crisis and its handling - had a strong influence on improving the situation between FDC and the farmers.

As described in more details below, we related the initial codes and themes to the preexisting conceptual ideas from the CAS framework. The third coding cycle consisted of elaborative coding, which is the process of analysing the coding (i.e. first and second cycles methods) in order to develop theory further, which is hence an appropriate method for qualitative studies that aim toward theory elaboration (Saldaña, 2009). This latter step offered a nuanced perspective of how the multilevel tensions can be explained by the CAS framework, supporting theory elaboration to encompass the idiosyncrasies of the case study. Beyond ensuring consistency in data reporting (Miles and Huberman, 1994), the combined expertise of the authors regarding SSCM and carbon measurement has ensured a critical analysis of the findings.

Despite the fact that numerous phenomena in SCM involve more than one level of theory and analysis, most SCM research still produces research at a single level (Carter et al., 
2015a). This paper offers advancements toward a multi-level perspective by adopting CAS as a framework that serves as a lens with which to investigate multi-actor behaviour and relationships (Mena et al., 2013). Second, it employs a multi-level analysis to understand levels nested within levels (Carter et al., 2015a). Our study shows how the engagement of the FDC's sustainability team at the consortium-level granted them access to pre-competitive collaboration. As a result, FDC was able to produce, with the help of a consultancy firm, the needed change at the individual level, i.e. changing suppliers' negative perception regarding the tool to a more collaborative approach. Moreover, behavioural change at the individual level produced changes at supply-network level, enabling data sharing, the development of a carbon emission baseline and driving reduction in carbon emissions.

As a result of our analysis we have obtained a nuanced account on how a carbon reduction strategy emerges, evolves and diffuses in a supply network. From a theory elaboration perspective (Fisher and Aguinis, 2017), our multilevel abductive approach has contributed to unpacking the constructs of CAS and the relationships between these constructs in the context of advancing sustainability in a supply network.

\subsection{Research quality}

Several mechanisms were used to ensure the overall quality and "trustworthiness" of the research (Shah and Corley, 2006, Lincoln and Guba, 1985). At the research design stage, particular attention was paid to the selection of participants and using previous literature to conceptually ground the research problem under study. During the data collection, extensive notes were taken and stored, interviews and meetings (when possible for the latter) were digitally recorded and transcribed to ensure accuracy. Transcripts were sent back to participants to ensure confirmability. Multiple informants and sources of information were used to ensure credibility, as shown in Tables 1,2 and 3. The long-term data collection process also ensures the credibility of the research. At the data analysis stage, the experience 
of several researchers was combined in order to address dependability and confirmability. The researchers who were not as closely involved in the data collection were able to bring a fresh perspective on the data. The researchers agreed on the approach to coding as explained in section 4.4. The analysis was conducted iteratively and independently by the researchers. The researchers compared their respective analysis and themes in order to reach agreement.

\section{Case study analysis}

In this section, we present the emergence of FDC's carbon reduction strategy for its crop A supply network from Year 1 to Year 5. The agents within FDC's crop A supply network are FDC's Sustainability and Buying teams, FDC's agricultural suppliers (farmers) and the environmental consultancy, Agri-consultancy. The FDC Sustainability team is also an agent within the SFT consortium. There were three phases to the process of transformation: Inception, Adaptation, and Quasi-equilibrium. The process is represented in Figure 3 below. The inception phase covers the first year of FDC's five-year strategy, the adaptation phase covers the second, third and beginning of fourth year and the quasi-equilibrium phase was initiated at the end of the fourth year.

\section{INSERT FIGURE 3 HERE}

\subsection{Phase One: Inception (Year 1)}

In Year 1, FDC set itself the ambitious target of reducing its carbon emissions by $50 \%$ between Year 1 and Year 5. Moreover, FDC extended this target to its supply network, which accounted for over $30 \%$ of its carbon footprint. In so doing, FDC has put farmers at the centre of its sustainability agenda. FDC faced a number of challenges however. They had ambitious targets that required farmers to double their carbon-efficiency, which would require a 
substantial change in their operations. The strategy depended upon their cooperation but FDC did not have the resources to facilitate this cooperation. Clearly, FDC needed to have a supplier engagement approach that would allow it to deliver its carbon reduction strategy.

In order to realize its carbon reduction strategy, FDC joined the SFT consortium in Year 1 as one of the first partner firms. From the perspective of CAS, the consortium exists within the environment of FDC's crop A supply network. We will show the extent to which FDC shares the schema of the consortium and how it has affected its behaviour.

The consortium was initially founded when a multinational, an NGO and a university formed a partnership to drive emissions reductions on farms. The consortium was launched and included other multinational companies, including FDC. With the inclusion of more corporate members, the consortium became a platform for pre-competitive collaboration. Their philosophy was that "what gets measured gets managed" and they developed the SFT as a farmer-friendly tool to help farmers measure their carbon footprints, identify carbon hotspots and ultimately reduce their emissions through the development and implementation of carbon reduction plans.

The SFT consortium is a way for organizations within food supply networks to share learning on carbon reduction in a non-competitive environment. One of their basic principles is that organizations would all benefit from the development of the SFT but would be able to reap individual benefits when implementing it in their own supply networks. Members do not share raw data. Instead, members share their learning in relation to using the tool through case studies (specific crops) and sharing stories of implementation (mostly the challenges).

Although the consortium aimed to develop and roll-out a farm-friendly tool, the boundaries of the consortium did not and do not extend to farmers. The schema of the consortium is very much that of the large multinational companies (consortium members), who view environmental sustainability in terms of measurable progress, scientific 
methodologies and impact reduction. The schema is very much in line with the strategic (top management) agendas of the multinationals - most of which have made pledges around impact reduction (FDC being one of the most ambitious). Their schema also assumes that the data from farming operations was already available or at least easily accessible through the farmers. Initially, the consortium had not considered how their members would engage their farmers to take ownership of the tool to support the members' carbon reduction strategies. A cooperative schema underpins the philosophy of the consortium. It is assumed that farmers will be willing to openly share the data collected through the SFT with other participants. The success of the SFT depends upon these assumptions about farmer behaviour being correct. In the case study, they were shown not to be. A comment by the only farmer present at the initial SFT meeting gave hint of the dynamics at play in the supply network:

"So really with this (referring to the SFT) they (referring to large companies) have found a new way of exploiting their farmers" (Only farmer participating in SFT meeting)

While membership of the consortium gave FDC legitimacy, it was unable to give them actual guidance on how the tool could be used to support their carbon reduction strategy. The success of FDC's strategy would depend heavily upon their farmers taking ownership of the SFT but FDC did not know how to engage their suppliers in the project initially. It took the first round of data collection through the tool to realise that a strategy had to be developed to engage farmers more effectively.

\subsubsection{Lack of unified sustainability schema within FDC}

During the case-study period, two teams were responsible for managing the carbon reduction strategy with the farmers: FDC's Sustainability and Buying teams. The Sustainability team was responsible for all aspects related to agricultural sustainability, including the introduction of new sustainability tools for suppliers. The Buying team was responsible for negotiating and monitoring contracts with suppliers. Initially, there was a conflict between the schemas 
of the two teams on how to implement FDC's carbon reduction strategy within the supply network.

The Sustainability team had a more eco-centric orientation focused on reducing carbon emissions. The Buying team had a more commercial perspective, treating the carbon reduction strategy as an add-on to their role. They initially had a fairly instrumental orientation towards the carbon reduction strategy and were only interested in those emissions reductions initiatives that also delivered cost reductions ("we aren't doing it because we want to save the planet", "as long as it makes business sense”). This was driven, at least in part, by the performance measures by which the Buying team were evaluated. While the Buying team was required to recommend inclusion of the environmental agenda in the famers' contracts, this element was not part of the buyers' key performance indicators. Instead, their performance was evaluated in terms of their ability to deliver cost reductions. The commercial perspective of the Buying team was also reflected through the farmers' accounts of the Buying team's approach:

"It has become much more an American ethos about goals and KPIs and price and everything like that..." (Farmer, Year 1)

"Thinking this is 50 years or something we've been growing for you, and it's just gone, just like that, because you are so pig headed and not understanding the economic situation that you're putting us all in, not just us, but everybody." (Farmer, Year 1)

Initially, the conflicting schema of the two teams undermined their ability to collaborate on the carbon reduction strategy as they each assigned a different priority to the carbon reduction strategy. This is evidence of the key role of the interaction between agents in the deployment of the carbon reduction strategy. Further, the tensions between the teams were apparent to some farmers, with negative effects upon their willingness to engage in FDC's carbon reduction strategy. 
"The area of difficulty as with any supply chain is the commercial aspect. And certainly, there are 2 parallel activities if you like. There is the work that FDC are doing on sustainability and then there is also the commercial and procurement theme alongside where there is a difficult relationship between the 2. And every year there are trading discussions in terms of how much FDC will pay for return of [crop As] and what the farmers expect to be paid. Now and again, for example in Year 1, those discussions can be quite tense and quite difficult." (Agri-consultancy team member, Year 2)

The relationship between the Sustainability and Buying teams was not entirely negative however, as the participation of the Sustainability team in the SFT consortium suggested to members of the Buying team that carbon reduction was a legitimate activity. The Sustainability team members who attended the consortium meetings also had the opportunity to discuss the issues they were facing within their organizations with other like-minded individuals who were facing the same challenges, notably around engaging commercial teams and suppliers. The consortium served a motivational purpose in this regard.

FDC's carbon reduction strategy was a means for them to reduce dimensionality within their crop A supply network. It was intended that the SFT would become the means through which farmers would take ownership of FDC's carbon reduction strategy. The top-down schema of the SFT consortium was incorporated into FDC's carbon reduction strategy through the Sustainability team, which was an agent in both the SFT consortium and FDC. The top down approach took the form of making it mandatory for their farmers to collect data and develop carbon reduction plans using the SFT. From the end of Year 1, this mandate was included in the supply contracts for crop A farmers.

"And it is contractualized around those elements now. That is where we have got to go.

We have delivered a consistent message to them and now we are getting to the point where 
we are contractualizing some of the requirements for ongoing carbon reduction and water management." (FDC Buying team member, Year 1)

\subsubsection{Conflicting sustainability schemas between the FDC teams and farmers}

The two FDC teams assumed that the farmers would either share their commitment to reducing carbon emissions or that emissions could be reduced through fiat, i.e. through inclusion within supply contracts. However, few farmers initially shared FDC's commitment to carbon reduction and the majority failed to see what they would gain from using the SFT. This perceived 'failure' of the farmers to understand and commit to the strategy was a source of continual frustration for the Sustainability team.

"I think that the farmers feel that there are lots of different things coming under the sustainability umbrella and then there are the other things like the commercial contract and also legislative programs. " (FDC Sustainability team member, Year 1)

The cause of these difficulties lay in the significant clashes between the schema of the two FDC teams and the farmers as well as FDC's initial failure to engage their farmers. The tensions are explored in detail below.

The farmers felt they had a more holistic view of the relationship between agriculture and the natural environment than FDC. The farmers talked about the farming tradition and the more tacit way of knowing about how to deal with agriculture. To them, FDC's focus on carbon reductions and data collection seemed a reductionist approach to sustainability. They viewed sustainability as a more holistic concept that included their role with nature and the community:

“We have a moral compass. As a farmer you can't run away from your farm, so your reputation is paramount. You can't decamp and set up a new business in a different city, you can't do that. You're living as part of the community." (Farmer, Year 1)

In the most extreme cases, the clash between the sustainability schemas of FDC and its 
farmers resulted in some farmers not being able to see the connection between carbon reduction and sustainability:

"Carbon is very alien, carbon is just something that they know they have got to reduce and then they know that FDC want to reduce it." (FDC Buying team member, Year 1)

An important part of FDC's sustainability schema was the urgency with which carbon emissions needed to be reduced within their crop A supply network and the scale of the changes required. As FDC were looking to reduce emissions by $50 \%$ within a five-year period, this dictated that the pace of change needed be quick. Farmers would need to learn how to use the SFT, set a baseline of current carbon emissions, and then develop and implement a plan for carbon reduction within a five-year period. This conflicted with the farmers' view of change, which tended to be less radical. Arguably, this is in line with the nature of the farmers' businesses. Most of the farmers are $3^{\text {rd }}$ or $4^{\text {th }}$ generation farmers and are often reluctant to radically change their practices, especially if they do not understand the reasons for the change being requested.

"Our farmers in the UK are very conservative, they don't want to change. They've inherited a system from their fathers and their fathers' fathers - their generation and the supplier's generation, and benefited on their farm, not just with us, with huge subsidies." (FDC Buying team member, Year 1).

The above issues resulted in many farmers not being able to understand FDC's emissions reductions strategy and their role within it. Many farmers had difficulties capturing the data that FDC needed. For example, it was unclear to many whether all of their emissions counted or solely those related to the crops produced for FDC.

Cooperation is a core principle within the sustainability schema of the SFT consortium and it is assumed that farmers will engage in the desired cooperative behaviour needed to drive down emissions. By putting the SFT at the heart of FDC's carbon reduction strategy, they 
became dependent on the willingness of farmers to share data information with FDC and with other farmers. The majority of farmers did not share the cooperative schema of the SFT consortium and Sustainability team however. There was a shared feeling amongst farmers that the data collected through the SFT would be used against them:

"What do they want to do with this data? Is it going to be used to negotiate harder?" (Farmer, Year 1)

The farmers had two concerns about using the SFT to collect and share data. Many farmers had doubts about how the information they shared would be used by the Buying team. For example, some farmers were expecting FDC to rank all their suppliers according to how well they performed on emissions and stimulate competition between them to increase or decrease the price paid per ton of crop A supplied. As a result, there was considerable uncertainty when the SFT was first rolled-out.

Many farmers saw the data related to the carbon emissions as proprietary information and as a possible means to gain a competitive advantage over other farmers supplying to FDC. Consequently, they were reluctant to share it with other suppliers.

The factors presented above contributed to farmers' lack of engagement in FDC's carbon reduction strategy and made them reluctant to take ownership of the SFT. Instead, farmers saw the SFT as just "another form" to fill in, i.e. a non-value adding activity that would consume valuable resources. Rather than engaging farmers around carbon reduction, FDC's strategy had instead led to many farmers perceiving that their relationship with FDC had become more formal and bureaucratic. The result was that the data collected in the first year of FDC's initiative were not accurate. Because the farmers saw the SFT as a box ticking exercise and an additional burden, many filled in the SFT with data that was not accurate simply to comply with their contractual obligations. This undermined FDC's attempt to establish an accurate emissions' baseline in the first year of their strategy. 
Findings from the inception phase are summarised in Table 4 below with illustrative quotes and corresponding CAS constructs.

INSERT TABLE 4 HERE

\subsection{Phase Two: Adaptation (Years 2-4)}

FDC had not anticipated that the farmers would respond so negatively to their strategy in general and the SFT in particular and that it would put such a strain on farmers. There was a perception among many farmers that FDC had managed the process of transformation poorly and had attempted to manage the process through fiat rather than through engagement. The irony of a farmer-friendly tool that the farmers had not been consulted on being imposed on them by fiat was not lost on many of the farmers.

"The fundamental problem was the process, the way they went about it was totally wrong, you know. It's a grower's tool. And they didn't just impose it, they went away and did their own work without engaging with people who understand it and do it and would ultimately be investing in it, they just did their own thing, bought it and then looked around to see who was going to use it. That's not a way of engaging." (Farmer, Year 2)

\subsubsection{Supplier engagement strategy}

FDC's challenge was to engage their suppliers on the issue of carbon reduction and to make the SFT more farmer-friendly. In the second year of the case study, FDC changed their approach. While the SFT remained at the centre of their strategy and its use by farmers was still mandated in contracts, FDC launched a supplier development plan to engage and support its farmers. Forums would be established to hear farmers' concerns and to better explain FDC's strategy. Training would be provided to farmers on how to collect accurate data and 
develop plans for reducing their emissions. These were organized as workshops given to groups of farmers on their farms.

The Sustainability team did not have the resources to support the scale of the supplier development that was required and turned to a third party, Agri-consultancy. Originally, Agri-consultancy had been engaged by FDC to help refine measures for carbon reduction, but their brief was expanded significantly in the second year in response to the challenges of implementation. They became responsible for rolling out the tool more widely but also for running a number of training sessions/workshops with the farmers.

"And, although something actually was completed and returned last year, they felt much more comfortable having been given more training on it. You know making sure that people fully understanding these tools. So that the data that they give is correct and therefore the information that they are getting back is appropriate and helpful." (Agri-consultancy team member, Year 2)

\subsubsection{Supplier learning}

There were a number of elements that contributed positively to making the suppliers more engaged with the SFT and FDC's strategy in general. Clearly the iterative approach to data collection for the SFT was an important learning curve for the farmers who became more acutely aware of the link between carbon measurement and the commercial viability of their business. In this sense, the schemas of the farmers became progressively more aligned with those of FDC. The role of Agri-consultancy was pivotal in supporting suppliers' learning. This is clear evidence of how the introduction of a new agent, and the relationships with existing agents have influenced the development of the initiative.

There were also external pressures that contributed towards supplier learning. For example, in Year 3 the farmers were facing an upcoming reform of the European Union's Common Agricultural Policy that put a strong emphasis on environmental sustainability. 
They were also facing requirements to reduce carbon from other customers and could therefore use their experience with FDC as a competitive advantage. This meant that the farmers became more attuned to FDC's sustainability agenda and to the importance of carbon reduction.

\subsubsection{Greater connectivity between FDC Buying team and farmers}

An initial barrier to farmers engaging with FDC's carbon reduction strategy was their growing distrust of the Buying team. Farmers perceived the team to be aggressive in its negotiations and assumed that the data would be used by the Buying team to strengthen their negotiating position relative to the farmers. The trust between farmers and FDC improved considerably in the period of the case study however due to the response of the Buying team to a crisis that affected the supply network in the fourth year of FDC's carbon reduction strategy.

Heavy rain in the UK in Year 3 resulted in poor harvests for many farmers, including FDC's crop A farmers. The Buying team responded to the crisis by listening to the farmers' concerns, providing support in dealing with adverse weather conditions and the impact this had on crop quality, and adjusting their buying price. This was viewed positively by farmers, who extended these positive feelings to FDC's carbon reduction strategy and became more willing to engage in data sharing and carbon reduction.

\subsubsection{Greater connectivity between FDC teams}

FDC is a 'data hungry' organization and as the SFT realized its potential to gather and process data, the relationship between the Sustainability and Buying teams improved. The carbon agenda gained legitimacy in the eyes of the Buying team. Thanks to the supplier engagement activities and the results achieved through the SFT, the Buying team was able to see measurable progress in terms of reaching the carbon reduction targets. They could discuss carbon measurement in a more concrete manner as the data was coming in, and this was an 
important learning point. The Buying team began absorbing a lot of information from the work conducted on the ground by the Sustainability team.

Findings from the adaptation phase are summarised in Table 5 below with illustrative quotes and corresponding CAS constructs.

INSERT TABLE 5 HERE

\subsection{Phase Three: Quasi-equilibrium (Years 4-5)}

By the end of the case study, FDC's crop A supply network had made the adaptations required, reaching a new state of quasi-equilibrium. FDC's strategy had raised awareness about carbon reduction among its farmers, created an accurate baseline for suppliers' emissions, and reduced emissions by $50 \%$ within 5 years. Further, FDC was able to deepen its relationship with its crop A farmers. Although many of them are considered heritage farmers, integrating environmental concerns within the context of the commercial relationship has resulted in an increase of shared information, communication and the development of a more collaborative relationship.

The consortium acted as a bridge for individuals from FDC between the macro concept of sustainability and the micro reality of implementing practices on the ground. It stopped individuals becoming too focused on the minutia and allowed them to keep seeing the bigger picture. Discussions at the consortium were as much about "global learning" and the "journey to sustainability" as they were about farm-level analysis.

FDC has made a number of contributions towards the consortium. One, its successes in engaging its suppliers on the issue of carbon reduction has encouraged other corporations to join the SFT consortium. Two, FDC has shared its experiences with the other members of the consortium through meetings and the production of a case study. As a result, the consortium 


\section{Discussion}

INSERT TABLE 6 HERE

Figure 4 provides a synthesis of the match between CAS elements and the case study.

\section{INSERT FIGURE 4 HERE}

This study provides a theoretically grounded perspective of the complexity inherent to the implementation of SSCM strategies. Van Bommel (2011: 899) points out that "only limited frameworks in the literature analyze and describe the process of implementing sustainability in supply networks". Through the lens of CAS, we provide a multilevel exploration of the processes at play in moving towards more environmentally sustainable supply networks. We have gained detailed longitudinal insights into both the agentic and environmental mechanisms that affect the transition for carbon reduction and have provided evidence for the criticality of contextual variables in making supply networks more environmentally sustainable. While the majority of previous research has often assumed linear and controlled views of greening strategies, this research on the other hand offers an emergent and somewhat 'messier' perspective to such strategies. This perspective enriches previous 
findings on the influence of institutional pressures on emergent SSCM practices (Zhu and Sarkis, 2007) but is also in line with the view that SSCM is fundamentally about change (Matthews et al., 2016).

We have used elements of CAS theory to make sense of the change process of making supply networks more environmentally sustainable, offered relevant explanations for the captured insights and have also elaborated on aspects of the CAS framework. This has enabled to formulate a number of propositions.

The notion of dimensionality proposed in CAS was particularly useful to understand the ways in which the focal firm as an agent member of the consortium was using the carbon reduction tool as a way to control the behaviour of the supplier agents. When the tool was first introduced a relative degree of freedom was given to the suppliers who had the prime responsibility to fill in the data onto the tool. Due to a poor farmer response in the first year, FDC's approach evolved to include more supplier engagement through the involvement of the consultants to support the implementation (delivering training sessions and sitting down with the farmers to fill in the questionnaire), which was an attempt for them to maintain higher levels of control over the transition process. Despite these control aspects, the carbon reduction strategy was characterised by self-organization and emergence. The nature of the relationships between the different agents meant that the implementation of the tool was not as straightforward as anticipated and new approaches emerged as well as new and stronger relationships, for instance between the suppliers and the consultants, and between FDC and the consultants.

Different schemas are noticeable in such a system. The SFT consortium and tool represented the dominant schema around carbon reduction in the food supply network, which is not that of the farmers/suppliers but of the large buying firms. Different schemas about the relationships were also held by individuals - suppliers had a fairly negative perception of the 
relationship at the beginning of the introduction of the SFT, which negatively affected their receptiveness to the tool and they became suspicious of FDC's intentions. The difference in understanding that resulted from the different schemas held by agents in the supply network was one of the most critical factors undermining the carbon reduction strategy initiated by the focal firm and leads us to the development of our first proposition below:

Proposition 1: The emergence of environmental strategies within supply networks is a non-linear evolutionary process and if the sustainability schemas of agents within those networks are not aligned, the less likely it is that the intended environmental strategy will be realized.

The case study complements previous research that suggests that transitioning to more sustainable practices with legacy suppliers may not be as smooth as one would expect and actually presents a number of challenges (Hoejmose and Adrien-Kirby, 2012). CAS as a framework appears however to underplay the power dynamics underlying internal mechanisms and co-evolution. In this research the SFT was included as part of the contracts for suppliers, who because of their dependence on the buyer, had limited choice but to implement it. The control exerted by the focal firm on the overall environmental strategy cannot be fully understood without considerations of both power and trust in the relationships between network agents. It also appears that because the consortium solely involves the large players in their role of buyers, it reinforces the existing top-down approach to SSCM rather than stimulate a change in relational dynamics. We therefore echo previous research, in particular in the food industry, which has found that power dynamics need to be taken into account in order to understand how to best advance sustainability practices (Touboulic et al., 2014, Hoejmose et al., 2013). Hence, in order to fully make sense of non-linear changes in supply networks, we must account for existing dependencies and power relations between the network agents. It is interesting to note that our findings confirm the idea that relying on a 
position of power in attempts to shape the environmental strategy of the supply network is insufficient to drive meaningful change.

While the exercise of power by the buying firm (FDC) had a negative effect upon the evolution of the carbon reduction strategy within the supply network, it was able to build goodwill with its suppliers through its response to an external event, the poor weather that negatively affected its farmers. Agents in the network may create goodwill with other members through their response to such events and change the attitudes and behaviours of other agents as a result, potentially facilitating the progression towards more sustainable practices. Our case suggests that goodwill may be able to better compensate for conflicting sustainability schema than the exercise of power by the buying firm.

The following propositions are based on the discussion of the contrasting roles that power and goodwill can play in facilitating the cooperation of agents within a supply network when there is a conflict between their sustainability schemas.

Proposition 2a: The power of buying firms will have limited capacity to change the behaviour of the supply network in the absence of shared sustainability schema.

Proposition 2b: Goodwill demonstrated by participating agents in the supply network may compensate for the lack of alignment between the sustainability schema of agents and thus facilitate the diffusion of environmental strategies.

Cooperative buyer-supplier relationships have been examined extensively within the SSCM literature as a means to drive change in supply networks (Gimenez and Sierra, 2013, Tachizawa et al., 2015, Gimenez and Tachizawa, 2012, Vachon and Klassen, 2006, Vachon and Klassen, 2007, Vachon and Klassen, 2008). Relationships with non-traditional network partners such as NGOs has been recognised as an important aspect of making supply networks sustainable (Gold et al., 2013, Pagell et al., 2010, Hartmann and Moeller, 2014, Wolf, 2011). While useful work has been conducted exploring collaboration between firms 
and NGOs (most notably Pagell and $\mathrm{Wu}, 2009$ ), it needs to be recognised that such initiatives do not always take the form of simple dyadic relationships. Many firms are finding it useful to participate in consortia to drive action on particular sustainability issues, such as climate change (Xu et al., 2016). As in our case study, participation in such consortia often takes the form of pre-competitive collaboration where competitors share research during the early stages of the innovation process (Ritala and Hurmelinna-Laukkanen, 2009, Gnyawali and Park, 2011).

The case study elaborates upon the original CAS framework by showing the important roles that other CAS in the external environment of the supply network, such as consortia, can play in the development and emergence of SSCM strategies. Further, the research showed that consortia can have a bridging and catalyst function for agents in supply networks. Consortia can help focal firms address the uncertainties of implementing sustainability in supply networks (Matos and Hall, 2007) by providing a platform to share experiences. The consortium in the case study ensured that agents did not lose sight of the bigger sustainability picture. It therefore bridged the micro means - the carbon reduction tool - with the macro idea of sustainability. In addition, the consortium played a motivational and legitimising role for individual agents who were often faced with difficulties in their own organizations. While much research has acknowledged the value of pre-competitive collaboration, their more intangible value needs to be recognised.

In a CAS, the role of external environmental factors is crucial in determining the evolution of the system. In this study, the boundaries of the system evolved in different ways, for example through the inclusion of Agri-consultancy as a critical agent. The role played by Agri-consultancy in this study was that of a key boundary spanning agent. Our findings in this respect resonate with the process model phases proposed by Nair et al (2016). Agriconsultancy's role and responsibilities were initially defined by FDC's structuring process 
whereby the dominant buying firms recognised that its limited resources and the conflicting schemas with suppliers constituted important barriers in the diffusion of its carbon reduction strategy. Agri-consultancy's role became pivotal in the diffusion and amplification of the carbon reduction strategy in the supply network through the developmental activities it ran with the suppliers and through its contribution and participation in the SFT consortia. Agriconsultancy has become a fundamental agent in the network, developing strong interorganizational links with the suppliers and FDC, and equally supporting the existing links between FDC and its suppliers by acting as a boundary spanner. It contributed to the institutionalisation of new practices as routines (SFT tool annual data collection) and to the synchronisation around carbon reduction in the supply network.

The preceding discussion leads us the development of our final propositions below:

Proposition 3a: Consortia are critical boundary spanning agents serving to bridge the micro practices in supply networks with the macro concept of sustainability and provide access to both tangible and intangible resources that can support the emergence and sustaining of a cohesive environmental strategy in the longer term.

Proposition 3b: Boundary spanning agents, comprising internal and external agents in the network, can help overcome existing conflicts between the schemas of agents and facilitate the proliferation of environmental strategies in the network.

\section{Conclusion, implications and future research}

In this study, we have focussed on the implementation of a sustainable farming tool as a means to achieve the carbon reduction in supply networks. We sought to understand how a carbon reduction strategy emerges in a supply network.

We have addressed our research question by offering insights into the emergent nature of a carbon reduction strategy across a supply network, drawing on a longitudinal case study and CAS as a theoretical framework. Findings from our study shed light on the multilevel, 
emergent and complexity aspects of driving carbon reduction in supply networks, therefore offering novel insights in the field of SSCM. Though SSCM strategies are generally reported as being top-down and rational, we explored the emergent aspects of such strategies and showed that individual and firm agents within the supply network, as well as agents and factors in the external environment, play a critical role in shaping the direction of such environmental strategy.

This paper contributes to SSCM research in three ways. First, we use the CAS framework (Pathak et al., 2007, Nair et al., 2009, Choi et al., 2001, Surana et al., 2005) to make sense of the process through which supply networks adapt in response to the challenges of environmental sustainability and the complexity inherent to this process of adaptation. Through an embedded case study, we provide an in-depth exploration of context, which in turn is used through abduction to confirm elements of the CAS framework and elaborate on others enabling us to formulate a number of propositions. Second, the focus on complexity has allowed us to explore the multilevel factors that influence the emergence of a carbon reduction strategy in a food supply network context, hence responding to recent calls for more multilevel research in the field (Carter et al., 2015a). Third, we contribute towards the incipient literature on consortia within SSCM by exploring the way in which buying firms use consortia to gain access to unique resources that can help initiate and sustain SSCM strategies. Specifically, we show how a consortium may act as a facilitator for change for sustainability in supply networks by providing platforms for non-competitive interaction.

The research yields several lessons for organizations and managers looking to adopt environmental strategies within their supply networks. Alignment of values, understandings and visions around sustainability and ways of working are crucial at two main levels. First, it cannot be assumed that suppliers will adopt a particular tool or change their behaviour if they do not see their values and beliefs integrated or represented in the strategy. Second, when 
multiple teams within the same organization are working with suppliers, they need to be sharing similar views and values about sustainability in order to communicate a coherent message and ultimately facilitate supplier engagement. There can also be an important role for intermediaries in this context to offer guidance in a neutral way e.g. through independent agronomists, unions, consultants, etc.

Another important lesson from this research is that SSCM strategies are organic processes and ultimately emerge because of cooperation and adjustments. This may suggest that transitioning towards more environmentally sustainable practices cannot be controlled or mandated and is not a top-down process. Sustainable supply networks are in constant flux and cannot be viewed as machines. Central to this is also the fact that managers should assume that their environment is dynamic. External factors such as the harvest crisis described in our case, while having disastrous consequences for the farmers, had a positive impact upon the carbon reduction strategy as FDC's supportive response to the crisis increased the farmers' willingness to engage in the strategy.

Our research seeks to sensitise managers to the dynamic and complex nature of the transition towards more sustainable practices in supply networks. It is crucial for managers to appreciate that the diffusion of environmental practices outside the boundaries of their organization may not be entirely within their direct control. Our case illustrated the value of working with boundary spanning actors in this context, such as the consortium that included consultancies and NGOs. The research therefore offers a more nuanced view of the role that dominant firms may play in support the transition to more sustainable supply networks. Indeed, rather than directing and controlling they may become orchestrators (Dhanaraj and Parkhe, 2006).

There are also societal implications that have emerged from our project. In particular, as discussed above consortia appear as central in promoting forums for horizontal collaboration 
and supporting the development and implementation of sustainability initiatives in supply networks. There are important roles to be played in these forums by societal agents such as Universities and NGOs, notably in providing access to the latest scientific developments and research around a particular sustainability issue. Individuals from these organizations also seem to be well placed to act as dialogue facilitators between competitors within the context of the consortium but also between agents in a supply network. Hence the project is evidence of the value of promoting industry - university collaboration.

Finally, our research has shown the value of taking part in consortia both for individuals and organizations seeking to become more sustainable. People or teams within an organization working on sustainability projects can gain access to innovative tools and ideas but will also be able to share the learning and experiences with like-minded individuals, which can sustain and inspire them especially in difficult times. At an organizational level, contributing to consortia can be a source of reputation.

The choice of a single case study was important to allow a multilevel analysis that encompasses the consortium level, the supply network level and the level of individuals. Yet, we acknowledge that there are limitations to using a single case study. The first limitation of single-case studies relates to control variables. Single cases do not allow researchers to control for variables such as environmental variations, firm size, and other aspects as in multiple-case research (Eisenhardt, 1989). Further, multiple-case research allows researchers to select categories or dimensions for analysis and then look for within-group similarities coupled with intergroup differences to expand understanding (Eisenhardt, 1989).

A second limitation of single-case research is the risk of placing too much emphasis on a single problem. When taking a single-case approach, researchers are often tempted to try to build theory that captures everything. The outcome can be a theory that is very rich in detail, but lacks the simplicity of an overall perspective (Eisenhardt, 1989). The idiosyncratic 
boundaries of a single setting can often lead to narrow and overly complex theoretical developments (Yin, 1994).

A third limitation is that the research considers the emergence of a carbon reduction strategy in the food sector, driven by a dominant buying firm. This concern with carbon reduction reflected the concern of the buying firm within the case but is clearly a reductionist construction of environmental sustainability - as was identified by the farmers in the case. Future research should seek to investigate the diffusion of environmental strategies more broadly and in other contexts. It would be interesting to explore the emergence and diffusion processes of environmental or social strategies initiated by suppliers or not-for-profit actors in their networks.

Another interesting avenue for future research would be to examine and test our propositions in similar and different contexts. Further studies could potentially seek to offer comparative evidence of other carbon decision support systems and tools. A logical step would be to explore how the other companies involved in the consortium have applied the tool. Comparative evidence from other sectors as well as other initiatives would also be useful. Finally, opportunities exist for the systemic application and exploration of theories that would complement CAS such as Social Network Theory and Ecological Modernization Theory. In particular, the latter would be relevant when seeking to understand the decisionmaking aspects of innovation diffusion and the interplay between bottom-up and top-down factors; while the former would enable refining the conceptualisation of linkages and relationships between agents and their influence on the evolution of the system.

\section{References}

Accenture 2009. Only One in 10 Companies Actively Manage Their Supply Chain Carbon Footprints, Accenture Study Finds. 
Alvarez, G., Pilbeam, C. \& Wilding, R. 2010. Nestlé Nespresso AAA sustainable quality program: an investigation into the governance dynamics in a multi-stakeholder supply chain network. Supply Chain Management: An International Journal, 15, 165-182.

Bai, C. \& Sarkis, J. 2010. Green supplier development: analytical evaluation using rough set theory. Journal of Cleaner Production, 18, 1200-1210.

Bai, C., Sarkis, J., Wei, X. \& Koh, L. 2012. Evaluating ecological sustainable performance measures for supply chain management. Supply Chain Management: An International Journal, 17, 78-92.

Bakker, E. F. \& Kamann, D.-J. F. 2007. Perception and social factors as influencing supply management: A research agenda. Journal of Purchasing and Supply Management, 13, 304-316.

Barratt, M., Choi, T. Y. \& Li, M. 2011. Qualitative case studies in operations management: Trends, research outcomes, and future research implications. Journal of Operations Management, 29, 329-342.

Bendell, J., Collins, E. \& Roper, J. 2010. Beyond partnerism: toward a more expansive research agenda on multi-stakeholder collaboration for responsible business. Business Strategy \& the Environment, 19, 351-355.

Benjaafar, S., Li, Y. \& Daskin, M. 2013. Carbon Footprint and the Management of Supply Chains: Insights From Simple Models. . IEEE Transactions on Automation Science and Engineering, 10, 99-116.

Beske, P., Land, A. \& Seuring, S. 2014. Sustainable supply chain management practices and dynamic capabilities in the food industry: A critical analysis of the literature. International Journal of Production Economics, 152, 131.

Bryman, A. 2012. Social Research Methods, New York, Oxford University Press.

Caniëls, M. C. J., Gehrsitz, M. H. \& Semeijn, J. 2013. Participation of suppliers in greening supply chains: An empirical analysis of German automotive suppliers. Journal of Purchasing and Supply Management.

Carbontrust 2006. Carbon Footprints in the Supply Chain: the next step for business London, UK.

Carter, C. R. \& Easton, P. L. 2011. Sustainable supply chain management: evolution and future directions. International Journal of Physical Distribution \& Logistics Management, 41, 46-62.

Carter, C. R., Meschnig, G. \& Kaufmann, L. 2015a. Moving to the next level: why our discipline needs more multilevel theorization. Journal of Supply Chain Management, 51, 94-102.

Carter, C. R. \& Rogers, D. S. 2008. A framework of sustainable supply chain management: moving toward new theory. International Journal of Physical Distribution \& Logistics Management, 38, 360-387.

Carter, C. R., Rogers, D. S. \& Choi, T. Y. 2015b. Toward the theory of the supply chain. Journal of Supply Chain Management, 51, 89-97.

Chaabane, A., Ramudhin, A. \& Paquet, M. 2012. Design of sustainable supply chains under the emission trading scheme. International Journal of Production Economics, 135, 37-49.

Choi, T. Y., Dooley, K. \& Rungtusanatham, M. 2001. Supply networks and complex adaptive systems: control versus emergence. Journal of Operations Management, 19, 351-366.

Cholette, S. \& Venkat, K. 2009. The energy and carbon intensity of wine distribution: A study of logistical options for delivering wine to consumers. Journal of Cleaner Production, 17, 1401-1413.

Cox, A., Chicksand, D. \& Palmer, M. 2007. Stairways to heaven or treadmills to oblivion?: Creating sustainable strategies in red meat supply chains. British Food Journal, 109, 689720. 
Denis, N., Fiocco, D. \& Oppenheim, J. 2015. From liability to opportunity: how to build food security and nourish growth. In: CO, M. (ed.).

Dhanaraj, C. \& Parkhe, A. 2006. Orchestrating innovation networks. Academy of management review, 31, 659-669.

Dubois, A. 2009. Comment on "Taking the leap from dyads to triads: Buyer-supplier relationships in supply networks" by Choi and Wu. Journal of Purchasing and Supply Management, 15, 267-268.

Dubois, A. \& Gadde, L.-E. 2002. Systematic combining: an abductive approach to case research. Journal of business research, 55, 553-560.

Dyer, W. G. \& Wilkins, A. L. 1991. Better stories, not better constructs, to generate better theory: A rejoinder to Eisenhardt. Academy of Management Review, 16, 613-619.

Ehrgott, M., Reimann, F., Kaufmann, L. \& Carter, C. R. 2011. Social sustainability in selecting emerging economy suppliers. Journal of Business Ethics, 98, 99-119.

Eisenhardt, K. M. 1989. Building theories from case study research. Academy of Management Review, 14, 532-550.

Eisenhardt, K. M. \& Graebner, M. E. 2007. Theory building from cases: opportunities and challenges. Academy of Management Journal, 50, 25-32.

Fadeeva, Z. 2005. Promise of sustainability collaboration - potential fulfilled? Journal of Cleaner Production, 13, 165-174.

Fisher, G. \& Aguinis, H. 2017. Using theory elaboration to make theoretical advancements. Organizational Research Methods, 1094428116689707.

Gimenez, C. \& Sierra, V. 2013. Sustainable Supply Chains: Governance Mechanisms to Greening Suppliers. Journal of Business Ethics, 116, 189-203.

Gimenez, C. \& Tachizawa, E. 2012. Extending sustainability to suppliers: a systematic literature review. Supply Chain Management: An International Journal, 17, 531-543.

Gnyawali, D. R. \& Park, B.-J. R. 2011. Co-opetition between giants: Collaboration with competitors for technological innovation. Research Policy, 40, 650-663.

Gold, S., Hahn, R. \& Seuring, S. 2013. Sustainable supply chain management in "Base of the Pyramid" food projects - A path to triple bottom line approaches for multinationals? International Business Review, 22, 784-799.

Granovetter, M. 1973. The strengths of weak ties. American Journal of Sociology, 78, 1360 1380.

Grimm, J. H., Hofstetter, J. S. \& Sarkis, J. 2014. Critical factors for sub-supplier management: A sustainable food supply chains perspective. International Journal of Production Economics, 152, 159.

Hamprecht, J., Corsten, D., Noll, M. \& Meier, E. 2005. Controlling the sustainability of food supply chains. Supply Chain Management: An International Journal, 10, 7-10.

Hartmann, J. \& Moeller, S. 2014. Chain liability in multitier supply chains? Responsibility attributions for unsustainable supplier behavior. Journal of Operations Management, 32, 281.

Henson, S. \& Humphrey, J. 2008. Understanding the complexities of private standards in global agri-food chains.

Hitchcock, T. 2012. Low carbon and green supply chains: the legal drivers and commercial pressures. Supply Chain Management: An International Journal, 17, 98-101.

Hoejmose, S., Grosvold, J. \& Millington, A. 2013. Socially responsible supply chains: power asymmetries and joint dependence. Supply Chain Management, 18, 277-291.

Hoejmose, S. U. \& Adrien-Kirby, A. J. 2012. Socially and environmentally responsible procurement: A literature review and future research agenda of a managerial issue in the 21 st century. Journal of Purchasing \& Supply Management, 18, 232-242. 
Hsu, C.-C., Tan, K. C., Zailani, S. H. M. \& Jayaraman, V. 2013a. Supply chain drivers that foster the development of green initiatives in an emerging economy. International Journal of Operations \& Production Management, 33, 656-688.

Hsu, C.-W., Kuo, T.-C., Chen, S.-H. \& Hu, A. H. 2013b. Using DEMATEL to develop a carbon management model of supplier selection in green supply chain management. Journal of Cleaner Production, 56, 164-172.

Hua, G., Cheng, T. C. E. \& Wang, S. 2011. Managing carbon footprints in inventory management. International Journal of Production Economics, 132, 178-185.

IPCC 2007. Climate Change 2007 synthesis report. Geneva: United Nations.

IPCC 2013. Climate Change 2013: The Physical Science Basis [Online]. http://www.ipcc.ch/report/ar5/wg1/\#.UoKXQRD0hEI. [Accessed 04/11/2013 2013].

Johnson, N., Elliott, D. \& Drake, P. 2013. Exploring the role of social capital in facilitating supply chain resilience. Supply Chain Management-an International Journal, 18, 324-336.

Jones, A. 2002. An Environmental Assessment of Food Supply Chains: A Case Study on Dessert Apples. . Environmental Management, 30, 560-576.

Kaufmann, L. \& Denk, N. 2011. How to demonstrate rigor when presenting grounded theory research in the supply chain management literature. Journal of Supply Chain Management, 47, 64-72.

Ketokivi, M. \& Choi, T. 2014. Renaissance of case research as a scientific method. Journal of Operations Management, 32, 232-240.

Koh, L., Genovese, A., Acquaye, A., Barratt, P., Rana, N., Kuylenstierna, J. \& Gibbs, D. 2013. Decarbonising product supply chains: design and development of an integrated evidence-based decision support system - the supply chain environmental analysis tool (SCEnAT). International Journal of Production Research, 51, 2092-2109.

Krause, D. R., Vachon, S. \& Klassen, R. D. 2009. Special topic forum on sustainable supply chain management: introduction and reflections on the role of purchasing management. Journal of Supply Chain Management, 45, 18-25.

Lamming, R. C., Johnsen, T. E., Zheng, J. \& Harland, C. M. 2000. An initial classification of supply networks. International Journal of Operations \& Production Management, 20, 675-691.

Lee, K.-H. 2011. Integrating carbon footprint into supply chain management: the case of Hyundai Motor Company (HMC) in the automobile industry. Journal of Cleaner Production, 19, 1216-1223.

Lee, K.-H. 2012. Carbon accounting for supply chain management in the automobile industry. Journal of Cleaner Production, 36, 83-93.

Lee, K.-H. \& Cheong, I.-M. 2011. Measuring a carbon footprint and environmental practice: the case of Hyundai Motors Co. (HMC). Industrial Management + Data Systems, 111, 961-978.

Lee, P. K. C., Lau, A. K. W. \& Cheng, T. C. E. 2013. Employee rights protection and financial performance. Journal of Business Research, 66, 1861-1869.

Lee, S.-Y. 2008. Drivers for the participation of small and medium-sized suppliers in green supply chain initiatives. Supply Chain Management: An International Journal, 13, 185198.

Lee, S.-Y. \& Klassen, R. D. 2008. Drivers and Enablers That Foster Environmental Management Capabilities in Small- and Medium-Sized Suppliers in Supply Chains. Production and Operations Management, 17, 573-586.

Lewis, M. A. \& Brown, A. D. 2012. How different is professional service operations management? Journal of Operations Management, 30, 1-11.

Lincoln, Y. \& Guba, E. 1985. Naturalistic Inquiry, Beverly Hills, CA, Sage. 
Maloni, M. J. \& Brown, M. E. 2006. Corporate Social Responsibility in the Supply Chain: An Application in the Food Industry. Journal of Business Ethics, 68, 35-52.

Matos, S. \& Hall, J. 2007. Integrating sustainable development in the supply chain: The case of life cycle assessment in oil and gas and agricultural biotechnology. Journal of Operations Management, 25, 1083-1102.

Matthews, L., Power, D., Touboulic, A. \& Marques, L. 2016. Building Bridges: Towards Alternative Theory of Sustainable Supply Chain Management. Journal of Supply Chain Management, 52.

Mckinnon, A. C. 2010. Product-level carbon auditing of supply chains: Environmental imperative or wasteful distraction? International Journal of Physical Distribution \& Logistics Management, 40, 42-60.

Mena, C., Humphries, A. \& Choi, T. 2013. Toward a theory of multi-tier supply chain management. Journal of Supply Chain Management, 49, 58-77.

Mena, C., Terry, L. A., Williams, A. \& Ellram, L. 2014. Causes of waste across multi-tier supply networks: Cases in the UK food sector. International Journal of Production Economics, 152, 144.

Miemczyk, J., Johnsen, T. \& Macquet, M. 2012. Sustainable purchasing and supply management: a structured review of definitions and measures at the dyad, chain and network levels. Supply Chain Management: An International Journal, 17, 478-496.

Miles, M. B. \& Huberman, A. M. 1994. Qualitative Data Analysis, London, Sage.

Nair, A., Narasimhan, R. \& Choi, T. Y. 2009. Supply networks as complex adaptative system: toward simulation-based theory building on evolutionary decision making. Decision Sciences, 40, 783-815.

Nair, A., Yan, T., Ro, Y. K., Oke, A., Chiles, T. H. \& Lee, S.-Y. 2016. How environmental innovations emerge and proliferate in supply networks: A complex adaptive systems perspectives. Journal of Supply Chain Management, 52, 66-86.

OECD 2010. Transition to a low-carbon economy: public goals and corporate practices, Paris, OECD Publishing.

Pagell, M. \& Shevchenko, A. 2014. Why research in sustainable supply chain management should have no future. Journal of Supply Chain Management, 50, 44-55.

Pagell, M. \& Wu, Z. 2009. Bulding a more complete theory of sustainable supply chain management using case studies of 10 exemplars. Journal of Supply Chain Management, 45, 37-56.

Pagell, M., Wu, Z. \& Wasserman, M. E. 2010. Thinking differently about purchasing portfolios: An assessment of sustainable sourcing Journal of Supply Chain Management, 46, 57-73.

Pathak, S., Day, J. M., Nair, A., Sawaya, W. J. \& Kristal, M. M. 2007. Complexity and adaptivity in supply networks: building supply network theory using a complex adaptive systems perspective. Decision Sciences, 38, 547-580.

Pinkse, J. \& Kolk, A. 2010. Challenges and trade-offs in corporate innovation for climate change. Business Strategy and the Environment, 19, 261-272.

Pullman, M. E., Maloni, M. J. \& Carter, C. R. 2009. Food for thought: Social versus environmental sustainability practices and performance outcomes Journal of Supply Chain Management, 45, 38-54.

Ritala, P. \& Hurmelinna-Laukkanen, P. 2009. What's in it for me? Creating and appropriating value in innovation-related coopetition. Technovation, 29, 819-828.

Rodrigue, J.-P. 2012. The geography of global supply chains: evidence from third-party logistics. Journal of Supply Chain Management, 48, 15-23. 
Rodríguez, J. A., Giménez Thomsen, C., Arenas, D. \& Pagell, M. 2016. NGOs' initiatives to enhance social sustainability in the supply chain: poverty alleviation through supplier development programs. Journal of Supply Chain Management, 52, 83-108.

Russell, S. 2011. Corporate Greenhouse Gas Inventories for the Agricultural Sector Washington, DC.

Saldaña, J. 2009. The Coding Manual for Qualitative Researchers, London, SAGE Publications.

Seuring, S. \& Müller, M. 2008. From a literature review to a conceptual framework for sustainable supply chain management. Journal of Cleaner Production, 16, 1699-1710.

Shah, S. K. \& Corley, K. G. 2006. Building better theory by bridging the quantitativequalitative divide. Journal of Management Studies, 43, 1821-1835.

Spence, L. \& Bourlakis, M. 2009. The evolution from corporate social responsibility to supply chain responsibility: the case of Waitrose. Supply Chain Management: An International Journal, 14, 291-302.

Stake, R. E. 1995. The Art of Case Study Research, SAGE Publications.

Surana, A., Kumara, S., Greaves, M. \& Raghavan, U. N. 2005. Supply-chain networks: a complex adaptive systems perspective. International Journal of Production Research, 43, 4235-4265.

Tachizawa, E., Gimenez, C. \& Sierra, V. 2015. Green supply chain management approaches: drivers and performance implications. International Journal of Operations \& Production Management, 35, 1546-1566.

Tachizawa, E. \& Wong, C. Y. 2014. Towards a theory of multi-tier sustainable supply chains: a systematic literature review. Supply Chain Management: An International Journal, 19, 643-663.

Tallontire, A. 2007. CSR and regulation: towards a framework for understanding private standards initiatives in the agri-food chain. Third World Quarterly, 28, 775-791.

Theißen, S., Spinler, S. \& Huchzermeier, A. 2014. Reducing the Carbon Footprint within Fast-Moving Consumer Goods Supply Chains through Collaboration: The Manufacturers' Perspective. Journal of Supply Chain Management, 50, 44-61.

Thompson, J. \& Scoones, I. 2009. Addressing the dynamics of agri-food systems: an emerging agenda for social science research. Environmental Science \& Policy, 12, 386397.

Touboulic, A., Chicksand, D. \& Walker, H. 2014. Managing imbalanced supply chain relationships for sustainability: A power perspective Decision Sciences, 45, 577-619.

UNEP. 2011. Towards a green economy: pathways to sustainable development and poverty eradication - a synthesis for policy makers [Online]. www.unep.org/greeneconomy. [Accessed 04/12/14].

Vachon, S. \& Klassen, R. D. 2006. Extending green practices across the supply chain. International Journal of Operations \& Production Management, 26, 795-821.

Vachon, S. \& Klassen, R. D. 2007. Supply chain management and environmental technologies: the role of integration. International Journal of Production Research, 45, 401-423.

Vachon, S. \& Klassen, R. D. 2008. Environmental management and manufacturing performance: The role of collaboration in the supply chain. International Journal of Production Economics, 111, 299-315.

Van Bommel, H. W. M. 2011. A conceptual framework for analyzing sustainability strategies in industrial supply networks from an innovation perspective. Journal of Cleaner Production, 19, 895-904. 
Van Der Vorst, J. G. a. J., Tromp, S.-O. \& Zee, D.-J. V. D. 2009. Simulation modelling for food supply chain redesign; integrated decision making on product quality, sustainability and logistics. International Journal of Production Research, 47, 6611-6631.

Vasileiou, K. \& Morris, J. 2006. The sustainability of the supply chain for fresh potatoes in Britain. Supply Chain Management: An International Journal, 11, 317-327.

Walker, H., Seuring, S. \& Klassen, R. D. 2014. Sustainable operations management: recent trends and future directions. International Journal of Operations \& Production Management, 34, -.

Whipple, J. M., Glenn Richey, R., Voss, M. D. \& Closs, D. J. 2009. Supply chain security practices in the food industry. International Journal of Physical Distribution \& Logistics Management, 39, 574-594.

Whiteman, G., Walker, B. \& Perego, P. 2013. Planetary Boundaries: Ecological Foundations for Corporate Sustainability. Journal of Management Studies, 50, 307-336.

Whittaker, C., Mcmanus, M. C. \& Smith, P. 2013. A comparison of carbon accounting tools for arable crops in the United Kingdom. Environmental Modelling \& Software, 46, 228239.

Wolf, J. 2011. Sustainable supply chain management integration: a qualitative analysis of the German manufacturing industry. Journal of Business Ethics, 102, 221-235.

WRI 1998. Safe climate, sound business: an action agenda. Washington, DC: World Resources Institute.

WRI \& WBCSD 2009. The Greenhouse Gas Protocol Initiative: Scope 3 Accounting and Reporting Standard, Review Draft. . Geneva, Switzerland.

WWF 2014. The living planet report: species and spaces, people and places. In: INTERNATIONAL, W. (ed.). Gland, Switzerland.

Xu, Y., Liu, J., Wu, J. \& Luo, C. 2016. Improving supply chain performance through industry standards use and community socialization. International Journal of Physical Distribution \& Logistics Management, 46, 763-782.

Yin, R. K. 1994. Case Study Research: Design and Methods, Porto Alegre, Bookman.

Yin, R. K. 2003. Case study research: Designs and methods, Thousand Oaks, CA, Sage

Zhu, Q. \& Geng, Y. 2013. Drivers and barriers of extended supply chain practices for energy saving and emission reduction among Chinese manufacturers. Journal of Cleaner Production, 40, 6-12.

Zhu, Q. \& Sarkis, J. 2007. The moderating effects of institutional pressures on emergent green supply chain practices and performance. International Journal of Production Research, 45, 4333-4355.

Zhu, Q., Sarkis, J. \& Lai, K.-H. 2013. Institutional-based antecedents and performance outcomes of internal and external green supply chain management practices. Journal of Purchasing and Supply Management, 19, 106-117. 
Table 1: Details of interviews

\begin{tabular}{|l|c|}
\hline Stakeholders/Participants & N \\
\hline FoodDrinkCo & $\mathbf{2 2}$ \\
\hline Head of sustainability team & 2 \\
\hline Head of UK agricultural sustainability programme & 2 \\
\hline Head of European agricultural sustainability programme & 1 \\
\hline Head of global agricultural sustainability programme & 2 \\
\hline European sustainable procurement manager & 2 \\
\hline Agricultural team manager & 1 \\
\hline Procurement manager for crop A & 1 \\
\hline Procurement manager for crops B \& C & 1 \\
\hline Agronomist & 1 \\
\hline Global health and agricultural policy manager & 1 \\
\hline European head of agriculture & 1 \\
\hline Manager global sustainable procurement programme & 1 \\
\hline Manager global sustainability programme & 1 \\
\hline Procurement manager & 1 \\
\hline Supply chain manager & 1 \\
\hline Environmental analyst & 1 \\
\hline Climate change and energy manager & 1 \\
\hline Sustainability data and reporting manager & 1 \\
\hline Suppliers & $\mathbf{1 5}$ \\
\hline Crop A & 10 \\
\hline Local merchant and farmer (owner/manager) & 1 \\
\hline Local merchant and farmer (FDC relationship manager) & 1 \\
\hline Local vegetable and cereal farmer 1 (owner/manager) & 1 \\
\hline Vegetable and cereal farming group (operations manager) & 1 \\
\hline Local vegetable and cereal farmer 2 (owner) & 1 \\
\hline Local vegetable and cereal farmer 2 (manager) & 1 \\
\hline Local farming group (owner) & 1 \\
\hline Local farming group (manager) & 1 \\
\hline Local vegetable farmer and packer (owner/manager) & 1 \\
\hline Local vegetable and cereal farmer 3 (owner/manager) & 1 \\
\hline Crop B & 1 \\
\hline Local merchants (owner/manager) & 2 \\
\hline Local producer (owner/manager) & 1 \\
\hline Crop C & 1 \\
\hline Regional agricultural merchant and supplier (owner/manager) & 1 \\
\hline Regional agricultural merchant and supplier (sustainability \\
manager) & 1 \\
\hline Local vegetable and cereal farmer (owner/manager) & 1 \\
\hline External stakeholders & 1 \\
\hline Agricultural consultancy & 1 \\
\hline Agricultural consultancy & 1 \\
\hline Agricultural consultancy & 1 \\
\hline SFT (deputy manager) & 1 \\
\hline Other SFT member (sustainability manager) & 1 \\
\hline TOTAL & 1 \\
\hline
\end{tabular}


Table 2: Details of other primary data sources

\begin{tabular}{|c|c|c|}
\hline Data type & $\mathbf{N}$ & Participants \\
\hline Workshops & 3 & \\
\hline FoodDrinkCo workshop & 1 & $\begin{array}{l}\text { Agricultural team manager, procurement } \\
\text { manager for crop A, head of UK } \\
\text { agricultural sustainability programme, } \\
\text { agricultural team manager, procurement } \\
\text { manager }\end{array}$ \\
\hline Suppliers of crop A workshops & 2 & $\begin{array}{l}\text { Local merchant and farmer } \\
\text { (owner/manager), Local vegetable and } \\
\text { cereal farmer } 1 \text { (owner/manager), } \\
\text { Vegetable and cereal farming group } \\
\text { (operations manager), Local vegetable and } \\
\text { cereal farmer } 2 \text { (owner), Local farming } \\
\text { group (owner) }\end{array}$ \\
\hline \multicolumn{3}{|l|}{ Observations, meetings and site visits } \\
\hline SFT Sponsors Meeting & 1 & $\begin{array}{l}\text { Representatives of SFT corporate members, } \\
\text { SFT managing director, SFT deputy } \\
\text { manager, }\end{array}$ \\
\hline Farmers Forum & 2 & $\begin{array}{l}\text { Farmers of Crop A, FDC agricultural team, } \\
\text { Procurement managers, agri-consultancy, } \\
\text { researcher }\end{array}$ \\
\hline Farmers meeting & 2 & $\begin{array}{l}\text { Farmers of Crop A, FDC agricultural team, } \\
\text { Procurement managers, researcher }\end{array}$ \\
\hline FoodDrinkCo European Sustainability meeting & 1 & $\begin{array}{l}\text { Members of the sustainability and } \\
\text { agricultural teams at FDC, other European } \\
\text { sustainability team members, researcher }\end{array}$ \\
\hline Sustainability Tradeshow & 1 & $\begin{array}{l}\text { Members of the sustainability and } \\
\text { agricultural teams at FDC, other European } \\
\text { sustainability team members, FDC } \\
\text { employees, researcher }\end{array}$ \\
\hline SFT meeting & 2 & $\begin{array}{l}\text { Representatives of SFT corporate members, } \\
\text { SFT managing director, SFT deputy } \\
\text { manager, Agri-consultancy members } \\
\text { working with FDC }\end{array}$ \\
\hline $\begin{array}{l}\text { FoodDrinkCo Sustainability Strategy Milestone } \\
\text { event }\end{array}$ & 1 & $\begin{array}{l}\text { Researcher, members of the sustainability } \\
\text { and agricultural teams at FDC, PR team, } \\
\text { journalists, Agri-consultancy members, } \\
\text { farmers of crop A, European sustainability } \\
\text { team members, policy-makers, MPs }\end{array}$ \\
\hline Farm visits & 11 & Farm owners/managers and researcher \\
\hline Meetings with sustainability and agricultural & 6 & $\begin{array}{l}\text { Research and members of the sustainability } \\
\text { and agricultural teams at FDC }\end{array}$ \\
\hline
\end{tabular}


Table 3: Details of secondary data sources (including both documents published and not publicly available)

\begin{tabular}{|l|l|}
\hline Document title/type & Date \\
\hline SFT Leadership Summit Report & Year 3 \\
\hline Internal FoodDrinkCo Newsletters (4) & $\begin{array}{l}\text { Year 1, Year 2, } \\
\text { Year 3, Year 4 }\end{array}$ \\
\hline Internal corporate sustainability strategy presentation & Year 2 \\
\hline Internal carbon footprinting progress presentation & Year 2 \\
\hline FoodDrinkCo agricultural sustainability programme videos (3) & $\begin{array}{l}\text { Year 2, Year 4, } \\
\text { Year 5 }\end{array}$ \\
\hline SFT Sponsors meeting report & Year 1 \\
\hline FoodDrinkCo Sustainable Farming Reports (2) & Year 1, Year 3 \\
\hline Internal FoodDrinkCo sustainable farming initiative draft survey & Year 4 \\
\hline FoodDrinkCo Sustainability Reports (4) & $\begin{array}{l}\text { Year 1, Year 2, } \\
\text { Year 3, Year 4 }\end{array}$ \\
\hline $\begin{array}{l}\text { Press release on celebrating achievements of sustainable } \\
\text { agriculture strategy }\end{array}$ & Year 6 \\
\hline
\end{tabular}


Table 4. Evidence of the emergence of the carbon strategy in the network: Inception phase

\begin{tabular}{|c|c|c|c|c|c|}
\hline \multicolumn{6}{|c|}{ Phase 1: Inception } \\
\hline \multicolumn{2}{|c|}{ CAS dimensions } & Key themes & $\begin{array}{l}\text { Level of } \\
\text { analysis }\end{array}$ & Exemplary events and actions & Illustrative quotes and evidence from the case \\
\hline \multirow{3}{*}{$\begin{array}{c}\text { Internal } \\
\text { mechanisms }\end{array}$} & \multirow{2}{*}{$\begin{array}{l}\text { Agents and } \\
\text { schema }\end{array}$} & $\begin{array}{l}\text { Dominant buying } \\
\text { firm translates } \\
\text { greening strategy } \\
\text { into specific goals } \\
\text { (i.e. carbon) }\end{array}$ & $\begin{array}{l}\text { Firm/supply } \\
\text { network }\end{array}$ & $\begin{array}{l}\text { Articulation of sustainability } \\
\text { strategy around priority areas in } \\
\text { Year } 1 \text { with carbon reduction at the } \\
\text { core } \\
\text { Ambitious target of } 50 \% \text { reduction } \\
\text { in GHG emissions in } 5 \text { years }\end{array}$ & $\begin{array}{l}\text { "Working with the Carbon Trust, we discovered } \\
\text { that the amount of carbon emitted in growing } \\
\text { crops such as crop A (...) was equal to all the } \\
\text { carbon used by our manufacturing sites. In fact, } \\
\text { growing crop A and sunflowers accounts for } 34 \% \\
\text { of the carbon footprint of our product" FDC } \\
\text { Sustainable Farming Report }\end{array}$ \\
\hline & & $\begin{array}{l}\text { Dominant buying } \\
\text { firm initiates } \\
\text { diffusion of carbon } \\
\text { reduction strategy } \\
\text { in network }\end{array}$ & $\begin{array}{l}\text { Firm/supply } \\
\text { network }\end{array}$ & $\begin{array}{l}\text { Life-cycle assessments conducted } \\
\text { prior to Year } 1 \text { used to support } \\
\text { focus on emissions reduction in } \\
\text { upstream network } \\
\text { Inclusion of carbon reduction } \\
\text { strategy as appendix to contracts }\end{array}$ & $\begin{array}{l}\text { "It's mandated because they wrote it in the } \\
\text { contract."(Farmer) } \\
\text { "There are } 6 \text { environmental requirements } \\
\text { stipulated in the current contract documentation } \\
\text { that they have got to achieve, including carbon } \\
\text { reduction"(Head of agricultural procurement) }\end{array}$ \\
\hline & $\begin{array}{l}\text { Dimensionality } \\
\text { (initially low) }\end{array}$ & $\begin{array}{l}\text { Lack of unified } \\
\text { sustainability } \\
\text { schema within } \\
\text { dominant buying } \\
\text { firm }\end{array}$ & Individual & $\begin{array}{l}\text { Differences in schemas within FDC } \\
\text { between sustainability and } \\
\text { commercial teams }\end{array}$ & $\begin{array}{l}\text { "We aren't doing it because we want to save the } \\
\text { planet" "As long as it makes business sense" } \\
\text { (Members of agricultural procurement team) }\end{array}$ \\
\hline Environment & $\begin{array}{l}\text { Dynamism (rules } \\
\text { and norms, new } \\
\text { connections) }\end{array}$ & $\begin{array}{l}\text { Development of } \\
\text { consortium and } \\
\text { tool }\end{array}$ & Consortium & $\begin{array}{l}\text { Partnership between large } \\
\text { multinationals, university and NGO } \\
\text { to provide evidence-based approach } \\
\text { to carbon management in food } \\
\text { supply chains } \\
\text { FDC becomes founding sponsor of } \\
\text { the SFT consortium }\end{array}$ & $\begin{array}{l}\text { The purpose of the SFT is "taking stock of our } \\
\text { personal and organizational journeys and setting } \\
\text { a common agenda: } \\
\text { 1. Sharing common challenges and lessons } \\
\text { learned about operationalizing sustainability } \\
\text { 2. Identifying needed Tools and approaches that } \\
\text { could be developed more efficiently in a pre- } \\
\text { competitive space"(SFT documentation) }\end{array}$ \\
\hline Co-Evolution & $\begin{array}{l}\text { Non-linear } \\
\text { changes }\end{array}$ & $\begin{array}{l}\text { Tensions between } \\
\text { the buying firm's } \\
\text { teams and }\end{array}$ & Individual & $\begin{array}{l}\text { Commercial and sustainability KPIs } \\
\text { not aligned within FDC }\end{array}$ & $\begin{array}{l}\text { "Sustainability is part and parcel of what we do. } \\
\text { We deal with nature, we are custodians of the }\end{array}$ \\
\hline
\end{tabular}




\begin{tabular}{|l|l|l|l|}
\hline & $\begin{array}{l}\text { suppliers } \\
\text { a) Conflicting } \\
\text { sustainability } \\
\text { schemas }\end{array}$ & $\begin{array}{l}\begin{array}{l}\text { Sustainability team focused on } \\
\text { carbon reduction and buying team } \\
\text { focused on contract negotiation }\end{array} \\
\text { b) Lack of } \\
\text { cooperative } \\
\text { schemas among } \\
\text { suppliers }\end{array}$ & $\begin{array}{l}\text { Inclusion of SFT carbon } \\
\text { measurement tool adoption in the } \\
\text { contracts } \\
\text { Low number of } \\
\text { responses/inaccurate responses to } \\
\text { the tool returned by farmers in the } \\
\text { first year } \\
\text { Perceived tension between } \\
\text { commercial pressures (competition } \\
\text { between farmers) and request to } \\
\text { share carbon data (cooperation) }\end{array}$ \\
\end{tabular}

countryside"

"It is 50\% in 5 years you know and the clocks keep running. We haven't got the luxury... And that is another barrier that we come up against. It is that farmers will always want to be $99.99 \%$ sure of something before making the change, maybe see it happen over 8 or 10 crop years but we haven't got the luxury of waiting that long to start affecting changes for things that affect the environment. It's kind of $50 \%$ in 5 years, one year is gone we have got 4 left so we have to take the learnings we have got and we have got to make some changes." (Farmer)

"And also, there are some tensions between the different farmer groups so it means there are

things that they consider as intellectual property and they don't wish to share with people outside of their particular group." (Buyer)

Table 5. Evidence of the emergence of the carbon strategy in the network: Adaptation phase

\begin{tabular}{|c|c|c|c|c|c|}
\hline \multicolumn{6}{|c|}{ Phase 2: Adaptation } \\
\hline \multicolumn{2}{|c|}{ CAS dimensions } & Key themes & Level of & Exemplary events and actions & Illustrative quotes and evidence from the case \\
\hline $\begin{array}{l}\text { Internal } \\
\text { mechanisms }\end{array}$ & $\begin{array}{l}\text { Agents and } \\
\text { schemas }\end{array}$ & $\begin{array}{l}\begin{array}{l}\text { Supplier } \\
\text { development }\end{array} \\
\text { a) Supplier } \\
\text { engagement }\end{array}$ & $\begin{array}{l}\text { Firm/supply } \\
\text { network } \\
\text { Individual }\end{array}$ & $\begin{array}{l}\text { Forums established to discuss } \\
\text { environmental strategy with } \\
\text { farmers } \\
\text { FDC delegated rolling out of the } \\
\text { tool to agri-consultancy } \\
\text { Agri-consultancy delivered training } \\
\text { sessions and workshops to farmers }\end{array}$ & $\begin{array}{l}\text { "And, although something actually was completed } \\
\text { and returned last year, they felt much more } \\
\text { comfortable having been given more training on } \\
\text { it. You know making sure that people were fully } \\
\text { understanding these tools. So that the data that } \\
\text { they give is correct and therefore the information } \\
\text { that they are getting back is appropriate and } \\
\text { helpful"(Agronomist) }\end{array}$ \\
\hline
\end{tabular}


Central role of bridging agents in Self-organisation and emergence facilitating

progression of environmental strategy in the network

SFT tool deployed in the network in search of increased control by FDC

Firm/supply network

Iterative data collection supported supplier learning

Firm/supply network as a controlas a contro
scheme
Agri-consultancy became fully responsible for delivering farmers' training and managing the data collection process.
"We are now rolling out the SFT to all our suppliers and it links industry recognised measures of CO2 to what we are doing " (Head of sustainable agriculture)

"The SFT helps support conversations with people on why carbon is important and how measuring it can bring business benefits" (Manager at Agri-consultancy)

"In order for carbon reduction to be implemented on farm, it is not sufficient for changes to realise carbon savings alone, they must also make financial sense and fit in with the overall farm business plan. Over the past five years we have been finding ways to achieve this. To date, this has included fitting invertors to in-store fans; increasing store insulation; switching to GPS for all tractor and sprayer operations; replacing irrigation pumps with more fuel efficient models; and changing the tractor fleet to a more fuel efficient make. Using the SFT has confirmed the carbon saving impact of these changes and has highlighted carbon emission hotspots." (Farmer) "I think as the project as evolved it became apparent that it's not just about methodology and science and it's actually an agricultural development type of project. And therefore I think one of the challenges has been to ensure that the project is fully inclusive with a collaborative approach." (Manager at Agri-consultancy) "FDC has engaged us to collect that data and to verify it, and to report it both to themselves and to 


\begin{tabular}{|c|c|c|c|c|c|}
\hline+ & L & & & & the farmers" (Consultant at Agri-consultancy) \\
\hline \multirow{3}{*}{ Environment } & $\begin{array}{l}\text { Dynamism - rules } \\
\text { and norms from } \\
\text { external agents }\end{array}$ & $\begin{array}{l}\text { Formalisation of } \\
\text { consortium and } \\
\text { tool based on } \\
\text { members' } \\
\text { experiences }\end{array}$ & Consortium & $\begin{array}{l}\text { Data being gathered through pilots } \\
\text { by participating members } \\
\text { Case studies developed and } \\
\text { compiled as publicly available } \\
\text { resources } \\
\text { Sharing the learning events } \\
\text { organised to discuss progress and } \\
\text { next steps } \\
\text { Increased membership to SFT } \\
\text { Agri-consultancy started taking part } \\
\text { in the SFT meetings }\end{array}$ & $\begin{array}{l}\text { SFT website and publicly available documents } \\
\text { Presentations at SFT meeting }\end{array}$ \\
\hline & \multirow[b]{2}{*}{$\begin{array}{l}\text { Dynamism - } \\
\text { changes and } \\
\text { unforeseen events }\end{array}$} & $\begin{array}{l}\text { Legal and } \\
\text { institutional } \\
\text { pressures influence } \\
\text { willingness to } \\
\text { comply with } \\
\text { environmental } \\
\text { strategy }\end{array}$ & $\begin{array}{l}\text { Firm/supply } \\
\text { network }\end{array}$ & $\begin{array}{l}\text { Reform of the European Union's } \\
\text { Common Agricultural Policy that } \\
\text { put a strong emphasis on } \\
\text { environmental sustainability }\end{array}$ & $\begin{array}{l}\text { "Everybody is moving in the same direction and } \\
\text { there is a lot of governmental and EU legislation } \\
\text { that's all driving the same thing." (Farmer) }\end{array}$ \\
\hline & & $\begin{array}{l}\text { Ad-hoc event } \\
\text { influences } \\
\text { goodwill in the } \\
\text { network }\end{array}$ & $\begin{array}{l}\text { Firm/supply } \\
\text { network }\end{array}$ & $\begin{array}{l}\text { Heavy rain in the UK resulted in } \\
\text { poor harvests for many farmers, } \\
\text { including FDC's farmers in their } \\
\text { crop A SC. } \\
\text { FDC Buying team responded to the } \\
\text { crisis by listening to the farmers' } \\
\text { concerns, providing support in } \\
\text { dealing with adverse weather } \\
\text { conditions }\end{array}$ & $\begin{array}{l}\text { "We're all in the same boat really, we were } \\
\text { short of spuds and they were short of spuds and } \\
\text { quality was poor and everybody's worked } \\
\text { together."(Farmer) } \\
\text { "FDC responded well" (Farmer) } \\
\text { "It was terrible to feel that you are letting your } \\
\text { customer down and seeing your farmers losing a } \\
\text { fortune."(Farmer) }\end{array}$ \\
\hline Co-Evolution & $\begin{array}{l}\text { Non-random } \\
\text { future }\end{array}$ & $\begin{array}{l}\text { Improved } \\
\text { relationship } \\
\text { between dominant } \\
\text { buying firm's } \\
\text { buying team and } \\
\end{array}$ & $\begin{array}{l}\text { Firm/supply } \\
\text { network } \\
\text { Individual }\end{array}$ & $\begin{array}{l}\text { Improved relationships and higher } \\
\text { levels of trust as a result of how the } \\
\text { weather crisis was handled } \\
\text { Farmers seeing the benefits of } \\
\text { implementing carbon management }\end{array}$ & $\begin{array}{l}\text { "They are always looking for the next problem or } \\
\text { the next challenge or the next opportunity and it is } \\
\text { good to work with companies that calibre" } \\
\text { (Farmer) }\end{array}$ \\
\hline
\end{tabular}


Table 6. Evidence of the emergence of the carbon strategy in the network: Quasi-equilibrium phase

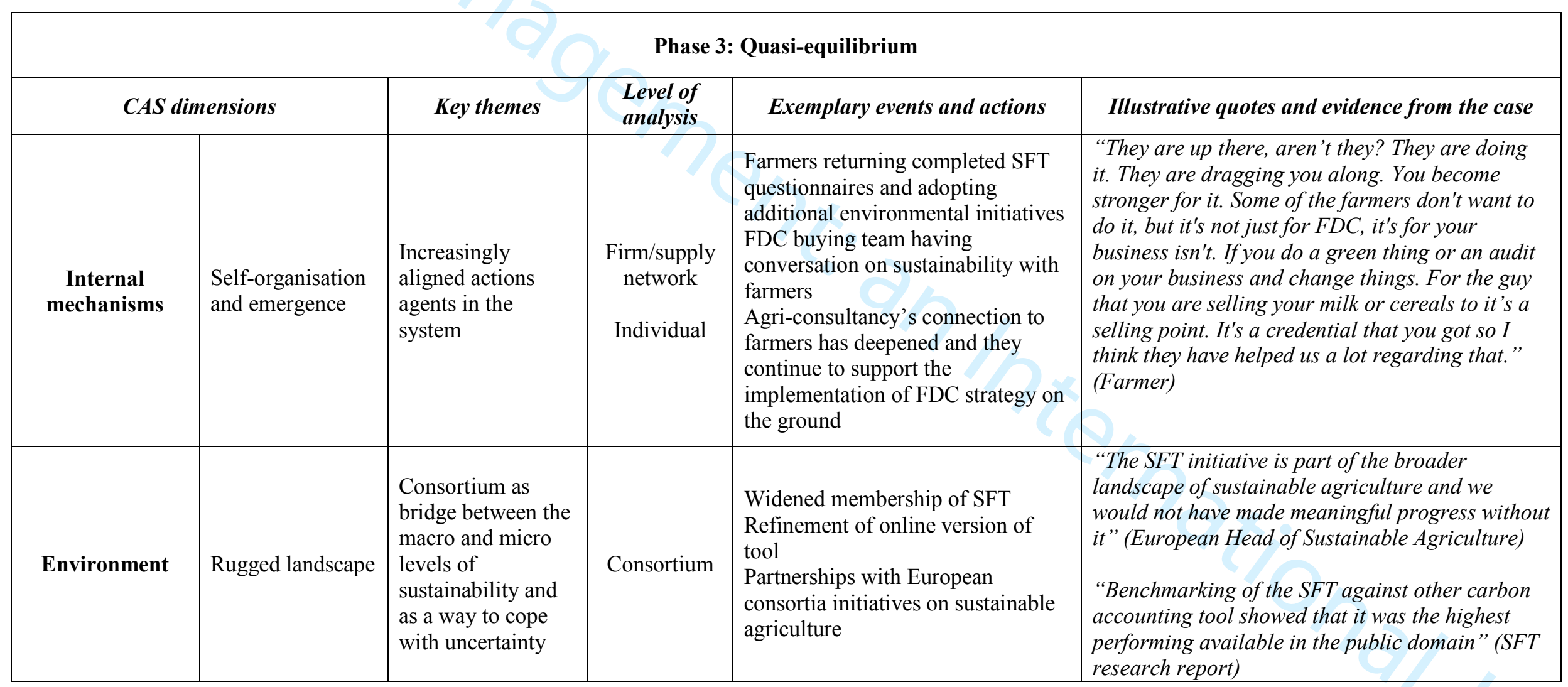

"Coming back to this year, if they carry on in the vein they're at over the last six months, you know, it would be great-it feels like their attitude has totally changed." (Farmer) 
Celebration of achievements in sustainable farming with event gathering FDC farmers, agriconsultancy, UK and European
Stability in the network with

Co-Evolution

Quasi-equilibrium teams, as well as policy-makers
Firm/supply network
FDC participating in industry

events as exemplar in sustainable agriculture

Farmers pursuing carbon

management plans
"In the UK we have achieved our ambitious environmental targets with our farmers. We've made great progress on our goal to halve our carbon footprint over a five-year period." (European Head of Sustainable Agriculture)

"I congratulate FDC, its partners and farmers on their achievements and look forward to exploring opportunities to build on this success." (Policy maker participant at celebration event)

"We are proud to be helping develop and implement more sustainable ways to farm, and we are applying the same principles that drove our carbon reduction strategy to other areas of our business." (FDC website) 
Figure 1. The original CAS framework (adapted from Choi et al., 2001)

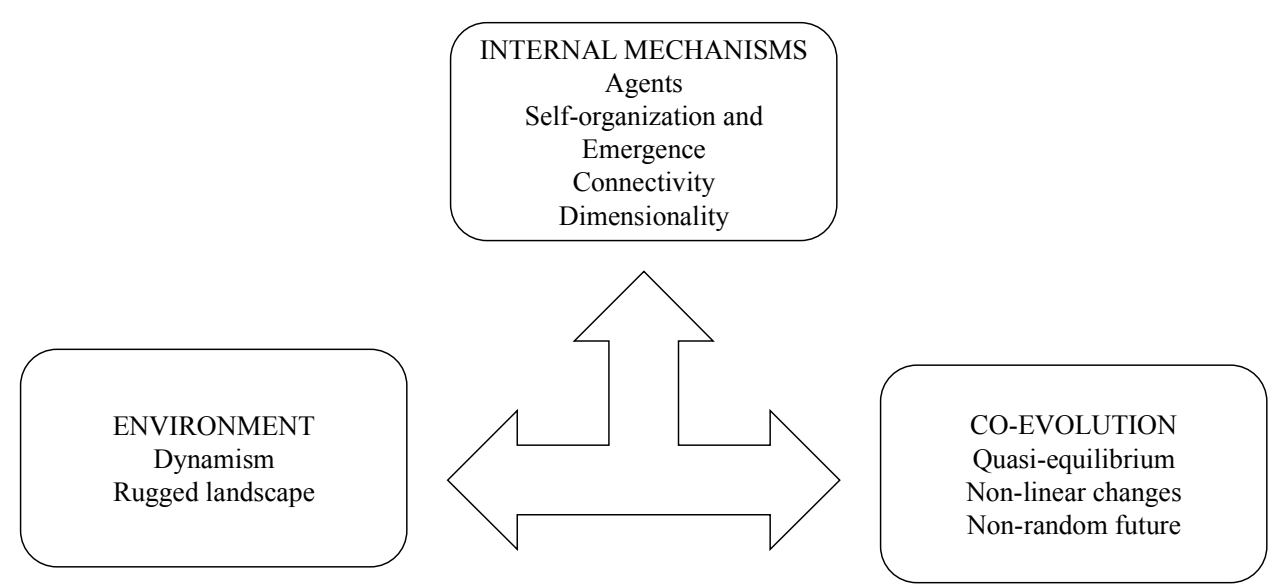


Figure 2. Case study boundaries (adapted from Touboulic \& Walker, 2015)

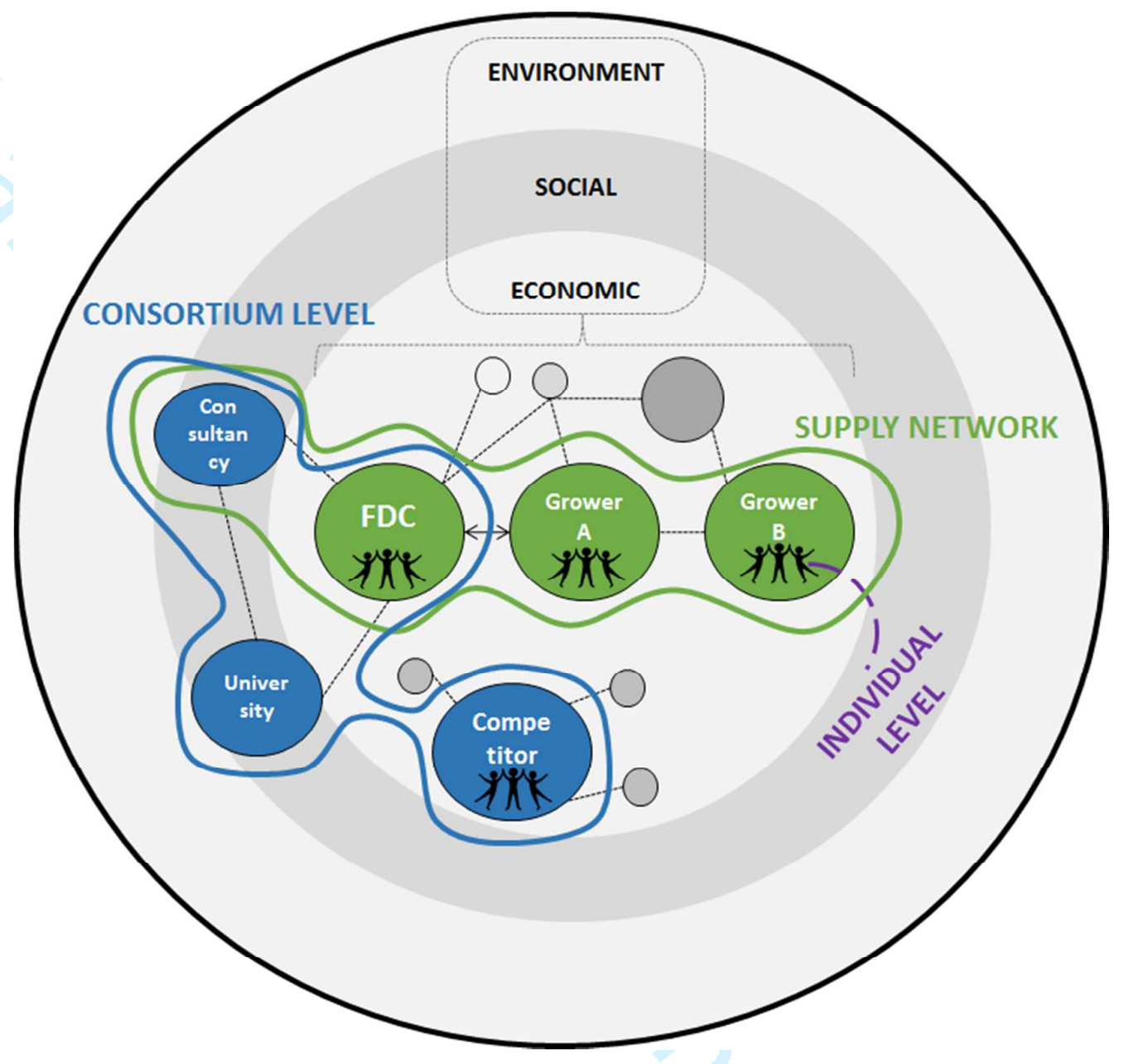




\section{Figure 3. The three-phase transformation process}

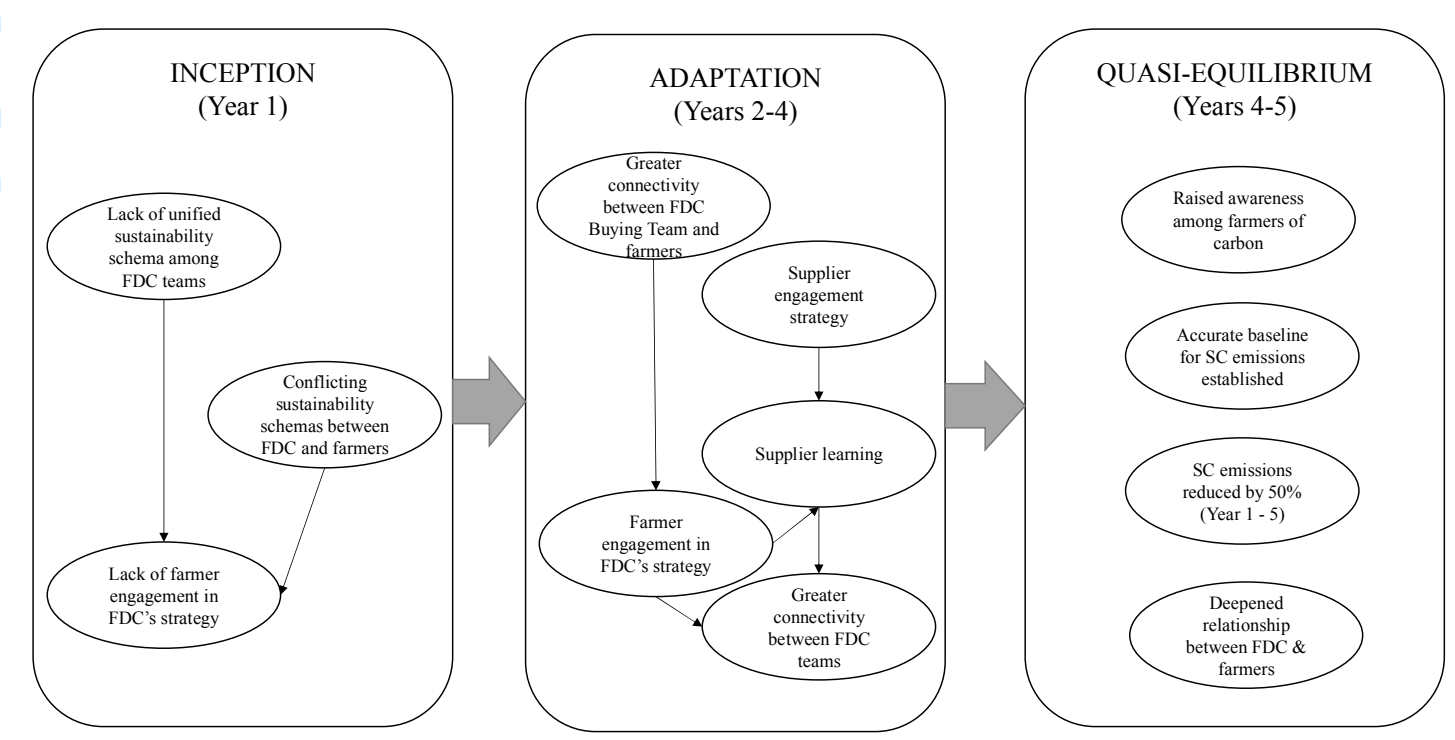

Figure 4. The CAS framework revisited with findings from the case study

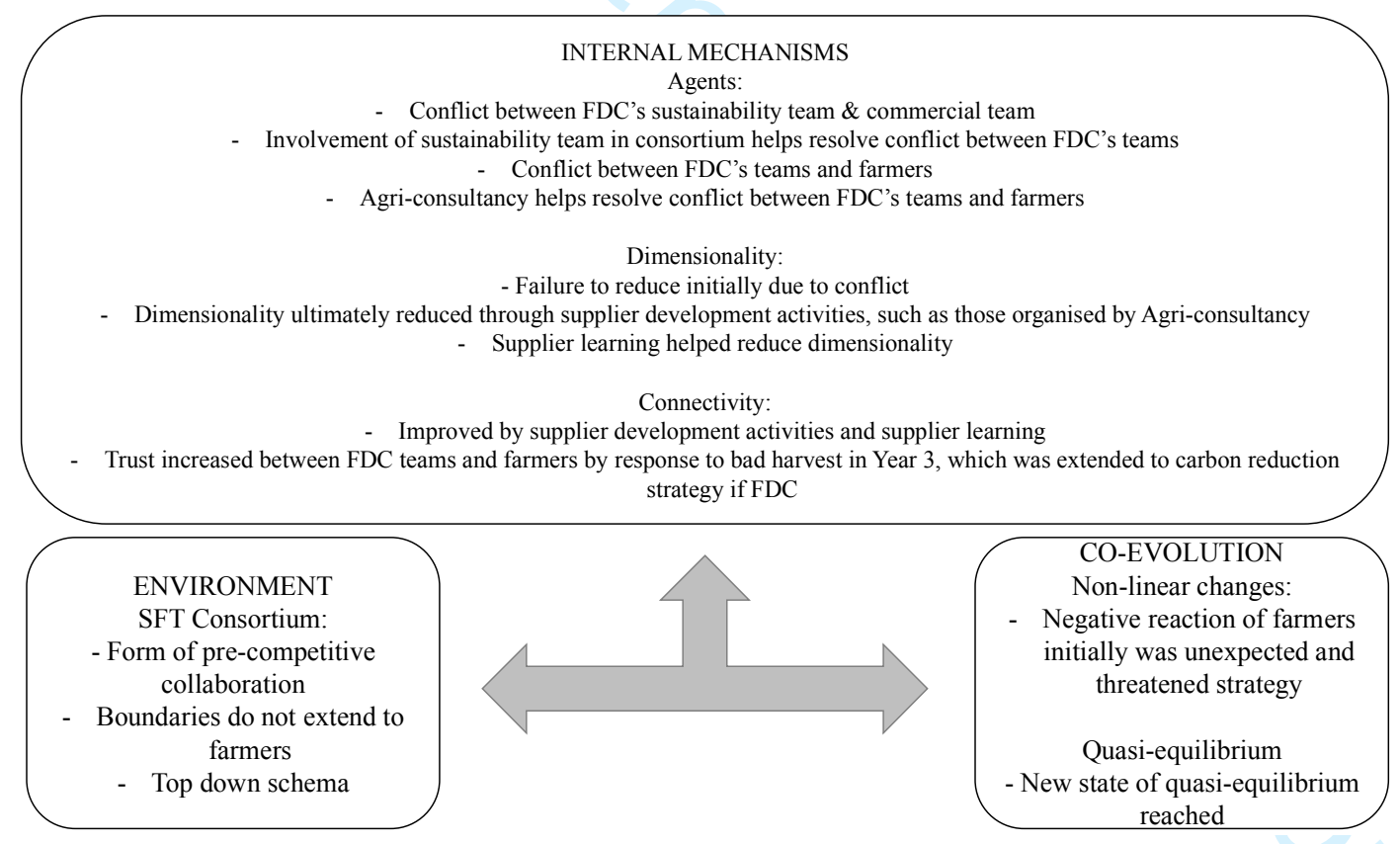

